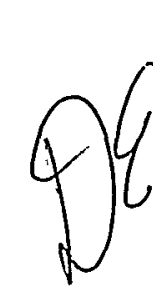

Q

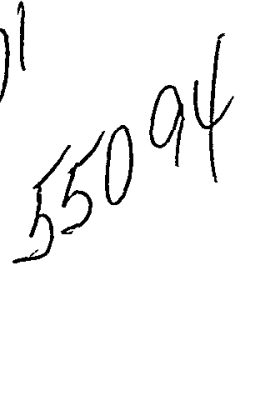

\section{FISCAL YEAR 1998 VEAR-END REPORT}

for the November 1997 to October 1998 Period

\title{
DECISION ANALYSIS AND TECHNOLOGY ASSESSMENTS FOR METAL AND MASONRY DECONTAMINATION TECHNOLOGIES
}

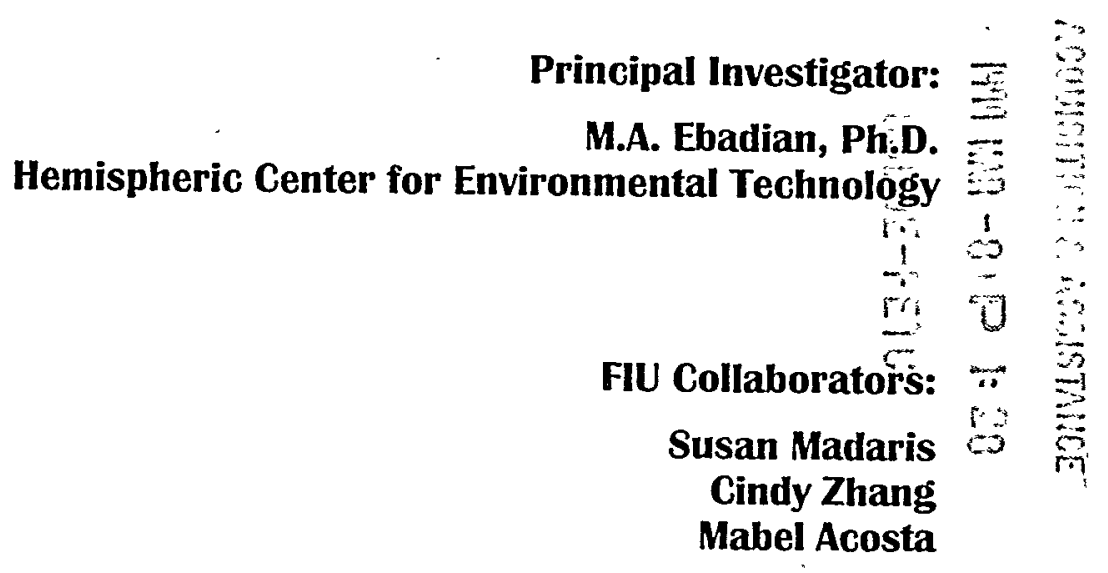

Prepared for:

Department of Energy Office of Science and Technology

Hemispheric Center for Environmental Technology (HCET) Florida International University, Center for Engineering \& Applied Sciences 10555 West Flagler Street, EAS-2100, Miami, Florida 33174 305-348-4238 - FAX: (305) 348-1852 - World Wide Web Site: http://www.hcet.fiu.edu

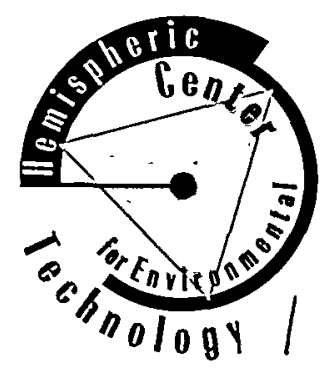




\section{DISCLAIMER}

This report was prepared as an account of work sponsored by an agency of the United States government. Neither the United States government nor any agency thereof, nor any of their employees, nor any of its contractors, subcontractors, nor their employees makes any warranty, express or implied, or assumes any legal liability or responsibility for the accuracy, completeness, or usefulness of any information, apparatus, product, or process disclosed, or represents that its use would not infringe upon privately owned rights. Reference herein to any specific commercial product, process, or service by trade name, trademark, manufacturer, or otherwise does not necessarily constitute or imply its endorsement, recommendation, or favoring by the United States government or any other agency thereof. The views and opinions of authors expressed herein do not necessarily state or reflect those of the United States government or any agency thereof. 


\section{DISCLAIMER}

Portions of this document may be illegible in electronic image products. Images are produced from the best available original document. 


\title{
DECISION ANALYSIS AND TECHNOLOGY ASSESSMENTS FOR METAL AND MASONRY DECONTAMINATION TECHNOLOGIES
}

\author{
Principal Investigator: \\ M.A. Ebadian, Ph.D. \\ Hemispheric Center for Environmental Technology \\ Florida International University \\ Miami, FL 33174
}

Florida International University Collaborators:

\section{Susan Madaris \\ Cindy Zhang \\ Mabel Acosta}

Hemispheric Center for Environmental Technology

Florida International University

Miami, FL 33174

$$
\text { January } 1999
$$

Prepared for:

U.S. Department of Energy

Office of Science and Technology

Under Grant DE-FG21-95EW55094 


\section{ACKNOWLEDGMENT}

This study has been made possible with the financial support of the Department of Energy, Office of Science and Technology. The Project Principal Investigator, Florida International University Collaborators, and students at Florida International University would like to thank Dr. Paul Hart for providing us the opportunity to work on this project. Special thanks to Barbara MaCabe, Bruce Lippy, Patrick Bell, Randy Nerris, David Curry, Jim Leslie, and Bill Nelson at the International Union of Operating Engineers, National Hazmat Program for their efforts in human factors assessment during technology evaluations. In addition, the authors would like to thank the Deactivation and Decommissioning (D\&D) group at Florida International University's Hemispheric Center for Environmental Technology (FIU-HCET) for their consistent support. 


$$
\longrightarrow \rightarrow \cdots
$$




\section{TABLE OF CONTENTS}

LIST OF TABLES. .

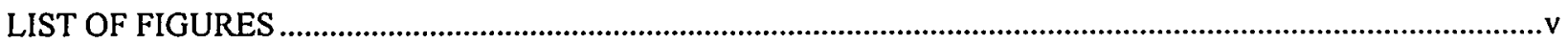

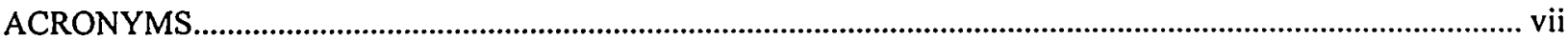

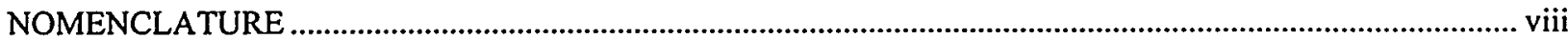

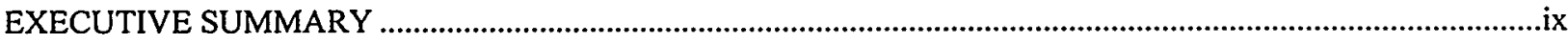

1.0 INTRODUCTION

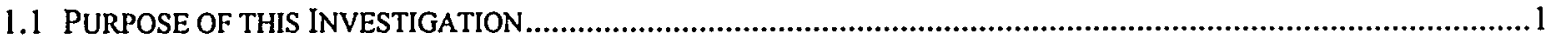

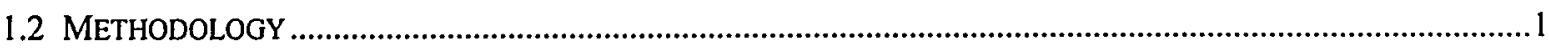

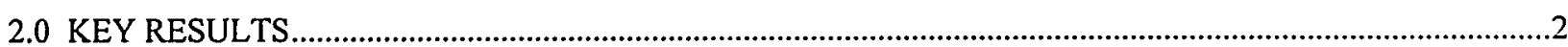

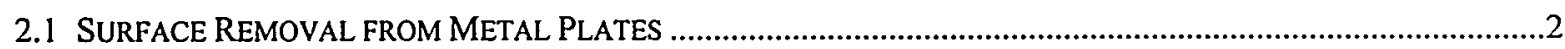

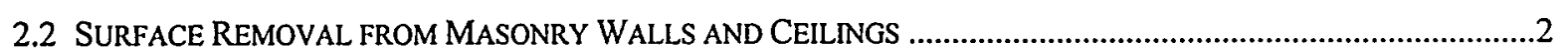

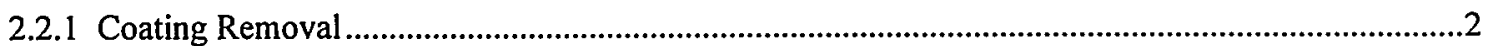

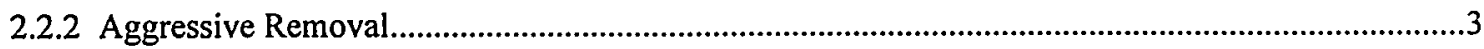

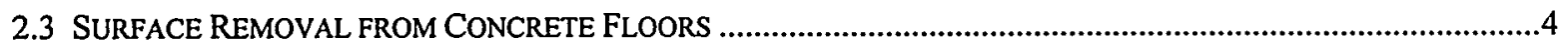

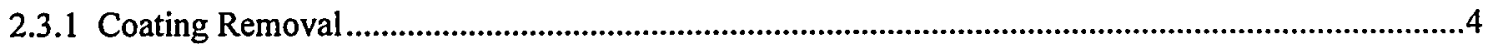

2.3.2 Aggressive Removal..............................................................................................................................

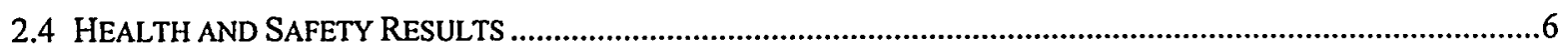

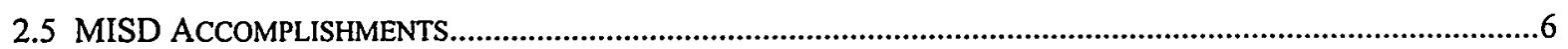

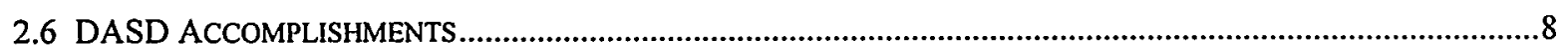

2.6.1 Completion of the Prototype of the DASD Software Application ...............................................

2.6.2 Distribution of the Prototype Software Application. Implementation of the enhancements suggested by D\&D professionals ......................................................................

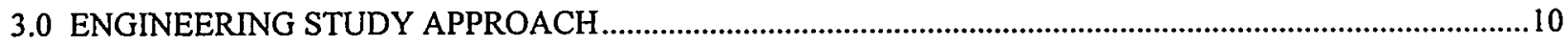

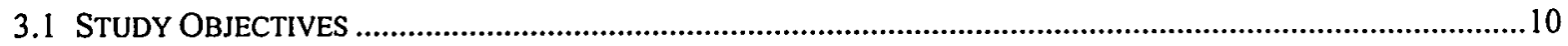

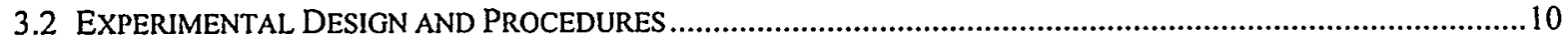

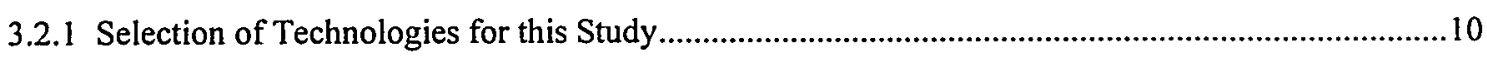

3.2.2 FIU-HCET Technology Assessment Site ................................................................................ 11

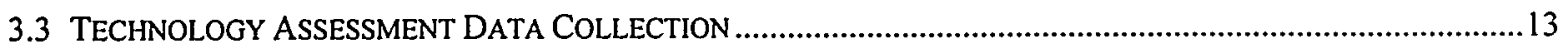

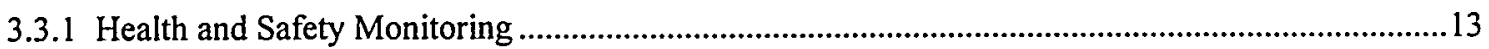

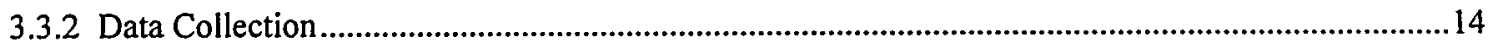

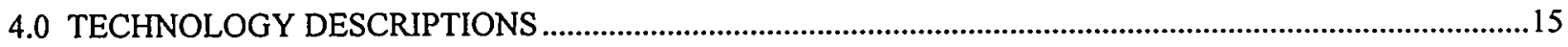

4.1 SURFACE REMOVAL FROM METAL PLATES ....................................................................................................

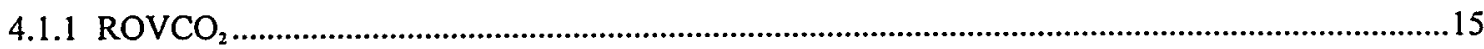




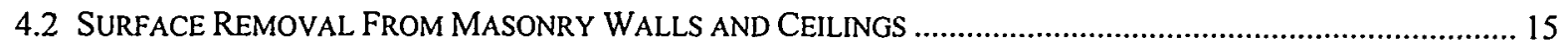

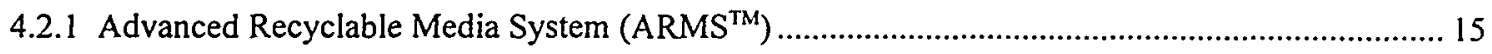

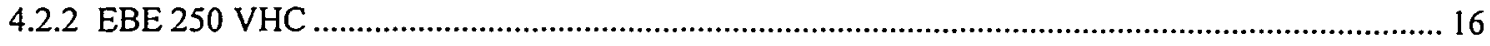

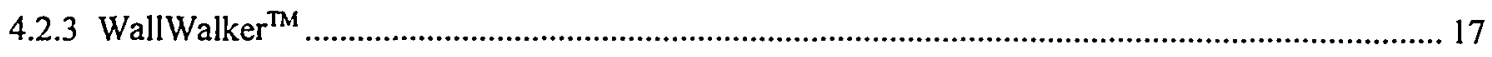

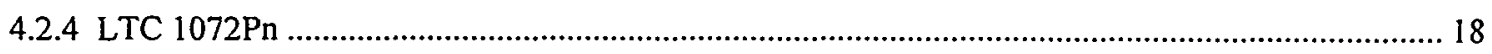

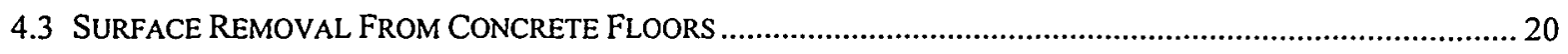

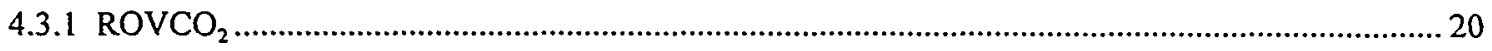

4.3.2 EBE 350

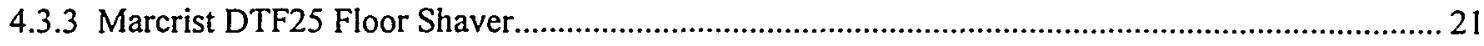

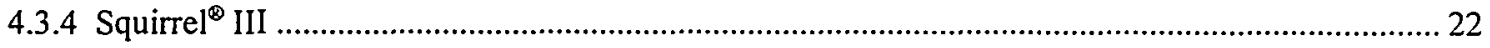

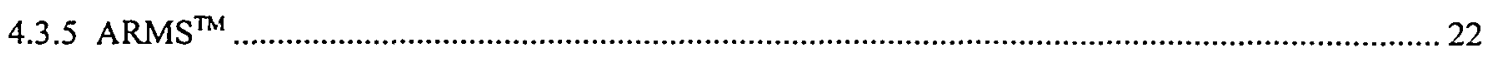

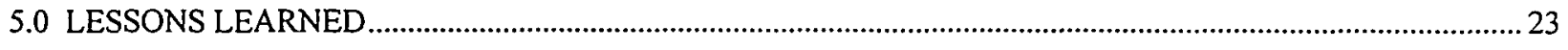

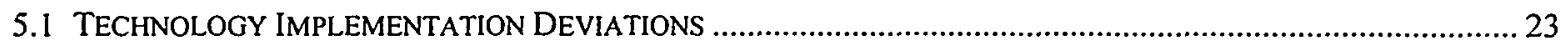

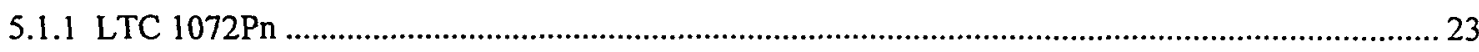

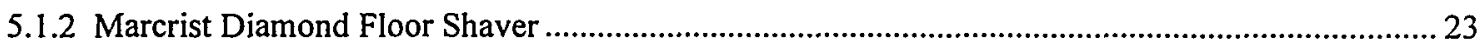

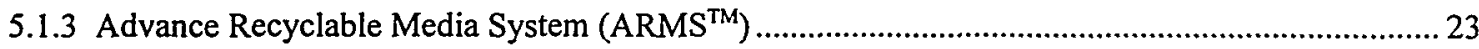

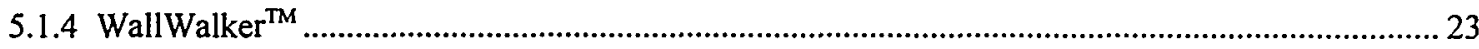

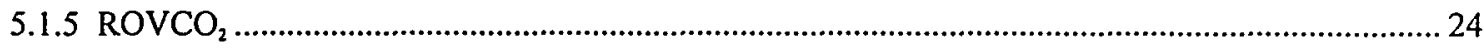

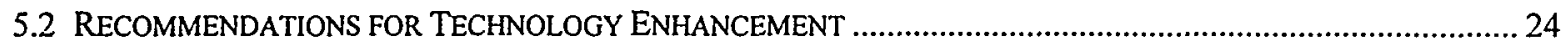

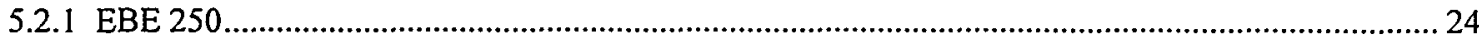

5.2.2 EBE 350

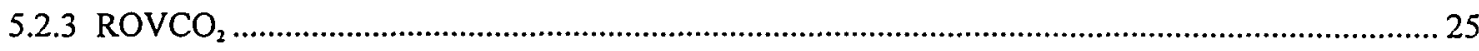

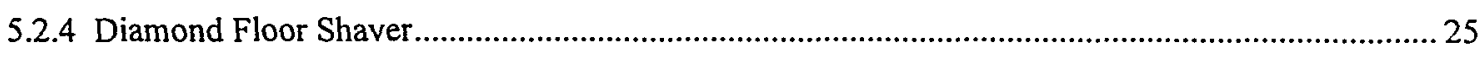

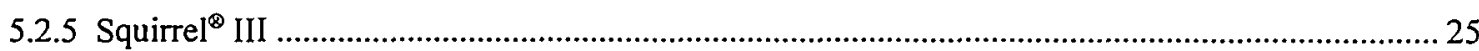

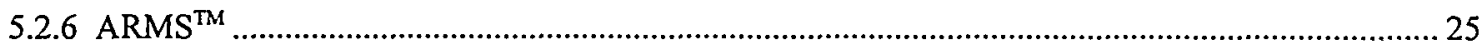

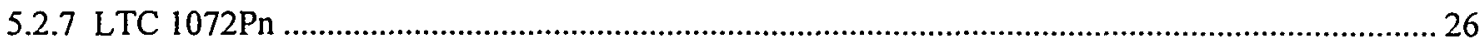

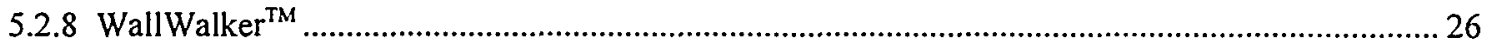

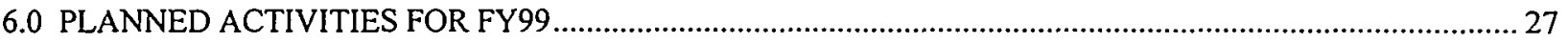

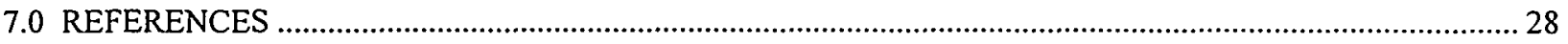

APPENDIX A: Technology Data Description

APPENDIX B: Technology Summary

B.l Technology Overview

B.2 Utility/Media Requirements

APPENDIX C: Technology Vendor Information

APPENDIX D: IUOE Human Factors Assessment Report Summary—Dust and Noise Data 


\section{LIST OF TABLES}

Table 1. Average Removal Gaps for Coating Removal

Technologies on Masonry Wall/Ceiling Surfaces ............................................................ 3

Table 2. Depth of Removal for Aggressive Removal

Technologies on Masonry Wall Surfaces ... 3

Table 3. Average Removal Gaps for Aggressive Removal

Technologies on Masonry Wall Surfaces

Table 4. Depth of Removal for Aggressive Removal Technologies on Concrete Floors 5

Table 5. Average Removal Gaps for Aggressive Removal

Technologies on Concrete Floors 6

Table 6. Status of Project Technical Plan for Multimedia System 7 


\section{LIST OF FIGURES}

Figure 1. Production Rates for Coating

Removal Technologies on Wall or Ceiling Surfaces .............................................. 2

Figure 2. Production Rates Achieved by

Aggressive Surface Removal Technologies on Masonry Walls

Figure 3. Production Rates Achieved by

Aggressive Removal Technologies on Concrete Floors

Figure 4a. FIU-HCET Technology Assessment Site Schematic .......................................... 11

Figure 4b. FIU-HCET Technology Assessment Site .................................................... 12

Figure 5. $\mathrm{ROVCO}_{2}$ Performing Coating Removal on a Steel Plate ..................................... 15

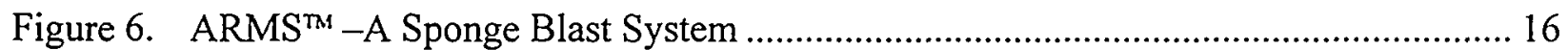

Figure 7. EBE 250VHC Operating on a Coated Brick Wall ............................................. 17

Figure 8. Wallwalker Operating on a Coated Concrete Wall ................................................. 18

Figure 9. LTC 1072Pn and LTC Air Cooler/Dryer .......................................................... 19

Figure 10. LTC America's Operator Decontaminating a Coated Brick

Wall Using the Articulating Arm ....................................................................... 19

Figure 11. $\mathrm{ROVCO}_{2}$ in Operation of Removing

Coating from a Concrete Floor 20

Figure 12. EBE 350 Operating on a Coated Concrete Floor ................................................. 21

Figure 13. Marcrist Floor Shaver Operating on a Coated Concrete Floor ............................... 21

Figure 14. Squirrel ${ }^{\circledast}$ III Operating on a Coated Concrete Floor ............................................... 22 


\section{ACRONYMS}

\begin{tabular}{|c|c|}
\hline $\mathrm{ACGIH}$ & American Conference of Governmental Industrial Hygienists \\
\hline AIHA & American Industrial Hygiene Association \\
\hline ARMS $^{\mathrm{TM}}$ & Advanced Recyclable Media System \\
\hline $\mathrm{D} \& \mathrm{D}$ & Deactivation (or Decontamination) and Decommissioning \\
\hline DASD & Decision Analysis System for Decontamination \\
\hline DOE & Department of Energy \\
\hline DOE-OST & Department of Energy - Office of Science and Technology \\
\hline $\mathrm{EBE}$ & European Blastcleaning Equipment \\
\hline FEMP & Fernald Environmental Management Project \\
\hline FIU & Florida International University \\
\hline FIU-HCET & $\begin{array}{l}\text { Florida International University - Hemispheric Center for Environmental } \\
\text { Technology }\end{array}$ \\
\hline FY97 & Fiscal Year 1997 \\
\hline FY98 & Fiscal Year 1998 \\
\hline HCET & Hemispheric Center for Environmental Technology \\
\hline IUOE & International Union of Operating Engineers \\
\hline IUOE-HAZMAT & International Union of Operating Engineers - National Hazmat Program \\
\hline MISD & Multimedia Information System for Decontamination \\
\hline NIOSH & National Institute for Occupational Safety and Health \\
\hline OSHA & Occupational Safety and Health Administration \\
\hline PPE & Personal Protective Equipment \\
\hline $\mathrm{ROVCO}_{2}$ & Remote Operated Vehicle with $\mathrm{CO}_{2}$ \\
\hline $\mathrm{R} \& \mathrm{D}$ & Research and Development \\
\hline SSPC & Steel Structures Painting Council \\
\hline
\end{tabular}




$\begin{array}{ll}\text { amp. } & \text { ampere } \\ \mathrm{cfm} & \text { cubic feet per minute } \\ \mathrm{dbA} & \text { decibels weighted on "A" scale } \\ \mathrm{ft} & \text { foot } \\ \mathrm{ft}^{2} / \mathrm{hr} & \text { square foot per hour } \\ \mathrm{in} . & \text { inch } \\ \mathrm{lb} & \text { pound } \\ \mathrm{mg} / \mathrm{m}^{3} & \text { milligram per cubic meter } \\ \mathrm{mm} & \text { millimeter } \\ \mathrm{psi} & \text { pounds per square inch } \\ \mathrm{TWA} & \text { Time weighted average }\end{array}$


HCET-1998-D032-011-04

\section{EXECUTIVE SUMMARY}

The U.S. Department of Energy's (DOE) Office of Science and Technology (OST), and Florida International University's Hemispheric Center for Environmental Technology (FIU-HCET) are conducting a comparative analysis of innovative technologies for the non-aggressive removal of coatings from metal and masonry surfaces and the aggressive removal of structural masonry up to one-inch thickness. Innovative decontamination technologies that are capable of being used in nuclear facilities are being assessed under standard, non-nuclear conditions at the FIU-HCET technology assessment site in Miami, Florida. This study is being performed to support the OST, the Deactivation and Decommissioning (D\&D) Focus Area, and the environmental restoration of DOE facilities throughout the DOE complex by providing objective evaluations of currently available decontamination technologies.

During fiscal year 1998 (FY98), eight decontamination technologies were evaluated at FIUHCET. These technologies can be classified into three categories: (1) coating removal from metal surfaces, (2) coating removal or aggressive removal from masonry walls and/or ceilings, and (3) coating removal or aggressive removal from concrete floors. The following is an executive summary of these technologies: ${ }^{a}$

- Coating removal from metal surfaces

Oceaneering International, Inc. - Remote Operated Vehicle with $\mathrm{CO}_{2}\left(\mathrm{ROVCO} \mathrm{O}_{2}\right)$. This innovative remote-controlled dry ice coating removal system removed coating from steel plates at a production rate of 4.22 square feet per hour $\left(\mathrm{ft}^{2} / \mathrm{hr}\right)$.

- Coating removal or aggressive removal from masonry walls and/or ceilings

Pegasus International, Inc. - European Blastcleaning Equipment Blastrac 250 (EBE 250 $V H C)$. This vertical shot blasting technology removed 0.25 inch from an uncoated concrete wall, a coated concrete wall, and a coated brick wall. The corresponding production rates were $13.60,12.59$, and $26.42 \mathrm{ft}^{2} / \mathrm{hr}$, respectively.

Pentek Inc. - WallWalker ${ }^{\mathrm{T}}$. Additional developments have taken place since this innovative robotic scabbling technology was evaluated at FIU-HCET in fiscal year 1997. The new system was designed to operate over two or three connecting walls, without repositioning the support mechanism after initial installation, thus improving production rate by reducing setup time for system repositioning. Additionally, the scabbler head demonstrated in FY98 was more powerful than the one used in FY97. Diameter of the scabbler bits has been increased from $13 / 8$ in. to $21 / 4$ in. Two important safety features have also been incorporated in the positioning trolleys. The new WallWalker ${ }^{\mathrm{TM}}$ removed 0.145 in. of coated concrete wall at a rate of $19.74 \mathrm{ft}^{2} / \mathrm{hr}$ and removed coating from brick wall surface at a rate of $31.58 \mathrm{ft}^{2} / \mathrm{hr}$.

a All removal depths reported in this executive summary were an average over the tested surface. The actual removal depth on each test surface varies depending on the technology. 
LTC Americas, Inc. - LTC 1072Pn Vacuum Blasting Machine. This grit blasting technology was evaluated for coating removal on metal surfaces at FIU-HCET in fiscal year 1995. Over the past year, LTC Americas has developed a new filter cleaning system, so-called "Concrete Filter Cleaning Valve" (CFCV). Using this new filtration system, the system could reduce downtime by blasting for longer periods before stopping to clean the filters. The new filtration system also allows the blast pressure to be increased by $50 \%$, which also results in improved productivity. In addition, the new LTC 1072 was coupled with a articulating arm with floor trolleys. With the articulating arm, operators were able to move a large blast head with ease. The improved system removed 0.19 in., 0.039 in., and coating from uncoated concrete wall surface, coated brick wall, and coated concrete ceiling, respectively. The corresponding production rates were $10.43,17.65$, and $25.19 \mathrm{ft}^{2} / \mathrm{hr}$, respectively.

Surface Technology Systems, Inc. (STS) - Advanced Recyclable Media System $\left(A R M S^{\mathrm{TM}}\right)$ ). Following the demonstration on a coated concrete wall and a concrete ceiling in 1997, the $\mathrm{ARMS}^{\mathrm{TM}}$ system, with a more efficient vacuum, was evaluated on a coated brick wall and a coated concrete floor in FY98. This sponge blasting technology removed coating from brick wall at a rate of $16.43 \mathrm{ft}^{2} / \mathrm{hr}$.

- Coating removal or aggressive removal from concrete floors

Oceaneering International, Inc. - Remote Operated Vehicle with $\mathrm{CO}_{2}\left(\mathrm{ROVCO}_{2}\right)$. This technology did not successfully remove coating from the concrete floor.

Pegasus International, Inc. - European Blastcleaning Equipment Blastrac 350 (EBE 350). This floor shot blasting technology removed 0.336 inch of uncoated concrete floor at a rate of $61.58 \mathrm{ft}^{2} / \mathrm{hr}$ and 0.324 inch of coated concrete floor at a rate of $65.17 \mathrm{ft}^{2} / \mathrm{hr}$.

Pegasus International, Inc. - Marcrist DTF25 Diamond Floor Shaver. This technology was capable of shaving concrete on horizontal surfaces by using a diamond blade. It removed 0.324 and 0.228 inch of concrete from coated and uncoated concrete floor, respectively. The corresponding production rates were 44.53 and $41.06 \mathrm{ft}^{2} / \mathrm{hr}$.

Pentek Inc. - Squirrel ${ }^{\circledR}$ III Floor Scabbler. This scabbling technology was evaluated as a baseline decontamination technology. It removed 0.192 in. of uncoated concrete floor at a rate of $13.72 \mathrm{ft}^{2} / \mathrm{hr}$ and $0.144 \mathrm{in}$. of coated concrete floor at a rate of $19.08 \mathrm{ft}^{2} / \mathrm{hr}$.

Surface Technology Systems, Inc. (STS) - Advanced Recyclable Media System (ARMS ${ }^{\mathrm{TM}}$ ). This technology removed most coating from a concrete floor at a rate of $26 \mathrm{ft}^{2} / \mathrm{hr}$. However, it was unable to remove some primer epoxy polyamine paint.

To better manage technology information and provide decision support to D\&D managers, FIUHCET has designed and is completing development of a Multimedia Information System for Decontamination (MISD) and a Decision Analysis System for Decontamination (DASD). MISD is a comprehensive multimedia-accessible database and information retrieval system of cost and performance data on technologies that have been demonstrated and assessed under FIU-HCET's Technology Assessment Program or at DOE's LSDDPs. DASD is a powerful analytical tool that allows D\&D Project Managers to define their site-specific decontamination needs and then 
searches the MISD database to identify the most suitable solutions. Data from over 30 decontamination technologies carried out at FIU-HCET are now being validated for input into the MISD database. The current system focuses on technologies and forms the blueprint for new applications covering dismantlement, characterization, and waste management. The MISD will be completed and ready for beta testing in the first quarter of 1999 . 


\subsection{INTRODUCTION}

There are approximately 10,000 buildings that require deactivation and decommissioning (D\&D) within the DOE's nuclear complex. Of these, some 1,200 buildings require dismantlement, decontamination, and safe disposal of an estimated 550,000 metric tons of metal and 23 million cubic meters of concrete contained in the floors, walls, ceilings, and support structures of these buildings. DOE continually seeks safer and more cost-effective innovative D\&D technologies for use in nuclear facilities and has invested in research and development (R\&D), testing, and evaluation of innovative D\&D technologies.

\subsection{PURPOSE OF THIS INVESTIGATION}

The purpose of this investigation was to conduct a comparative analysis of innovative technologies for the non-aggressive removal of coatings from metal and masonry surfaces and the aggressive removal of one-quarter to one-inch thickness of surface from structural masonry. The technologies tested should be capable of being used in nuclear facilities. Innovative decontamination technologies are being evaluated under standard, non-nuclear conditions at the FIU-HCET technology assessment site in Miami, Florida. This study is being performed to support the OST, the Deactivation and Decommissioning (D\&D) Focus Area, and the environmental restoration of DOE facilities throughout the DOE complex by providing objective evaluations of currently available decontamination technologies.

\subsection{METHODOLOGY}

FIU-HCET provides a test site where various types of surfaces were constructed to simulate walls and ceilings found at DOE remediation sites. FIU-HCET continually solicits proposals from potential technology vendors for evaluation of their technology over the surface areas specified. Technology vendors were responsible for optimizing the operation of their technology over the surface area(s) specified. During the operation of the technology, FIU-HCET evaluators collected data for the technology's production rate, technology model maneuverability, removal depth, removal gap, removal media usage rate, ending surface condition, primary/secondary waste volume generated during the demonstration, mobilization and demobilization times, operational and maintenance requirements, environmental conditions produced by technology operation, and technology benefits and limitations. Additional data were collected from the vendor including equipment capital costs, maturity of technology, applicable surface media and geometries, removal capability, technology availability, equipment maintenance, utility requirements, and previous job site experience. Representatives of the International Union of Operating Engineers (IUOE) were also on-site to assess the technology with regard to health and safety factors. Photographs and video were used to document the technology in operation. 


\subsection{KEY RESULTS}

This section provides an overview of some of the most significant technology performance data obtained during this project.

\subsection{SURFACE REMOVAL FROM METAL PLATES}

During FY98, the only technology that was evaluated on metal surfaces was Oceaneering International's $\mathrm{ROVCO}_{2}$ system. The technology was able to remove coating from metal plates at a production rate of $4.22 \mathrm{ft}^{2} / \mathrm{hr}$. The average removal gap for this technology was approximately 7 inches. Removal gaps represented the distance between the edge of the surface media and an adjacent surface that one technology was not able to reach.

\subsection{SURFACE REMOVAL FROM MASONRY WALLS AND CEILINGS}

\subsubsection{Coating Removal}

During FY98, three technologies were evaluated for coating removal from masonry walls or ceilings. They were Surface Technology System's ARMS ${ }^{\mathrm{TN}}$ - a sponge blasting technology, LTC America's LTC 1072Pn-a grit blasting technology, and Pentek's WallWalker ${ }^{\mathrm{TM}}$ - $\mathrm{a}$ robotic scabbling technology. Both ARMS ${ }^{\text {TM }}$ and WallWalker ${ }^{\mathrm{TM}}$ successfully removed coating from brick walls, while LTC 1072Pn successfully removed coating from concrete ceiling. Production rates achieved by these technologies are demonstrated in Figure 1. Table 1, on the other hand, presents average removal gaps observed during each technology evaluation. Information on these coating removal technologies is valuable for site personnel requiring a lesser degree of surface removal or for delicate surfaces where damage to the substrate is not desirable.

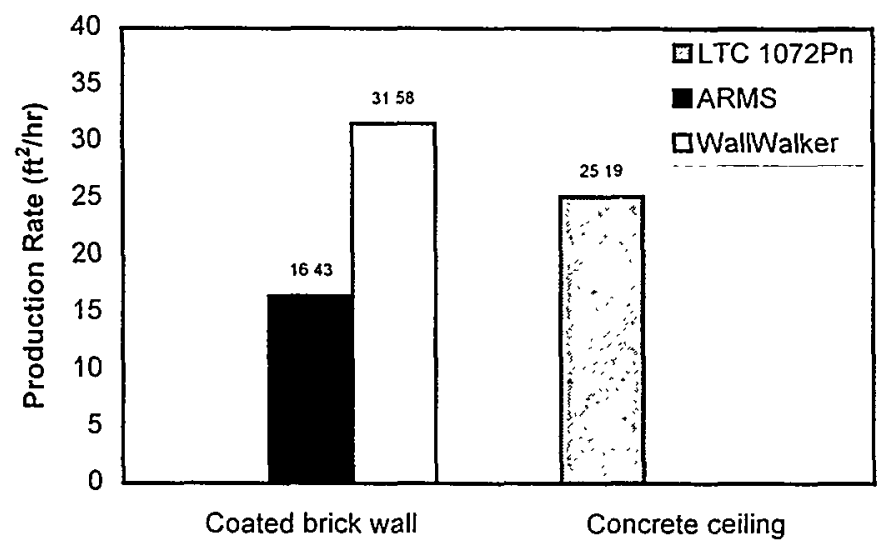

Figure 1. Production rates for coating removal technologies on wall or ceiling surfaces. 
Table 1.

Average removal gaps for coating removal technologies on masonry wall/ceiling surfaces

\begin{tabular}{|l|c|c|c|c|}
\hline Technology & Surface Type & $\begin{array}{c}\text { Ceiling to Wall } \\
\text { Interface (in.) }\end{array}$ & $\begin{array}{c}\text { Floor to Wall } \\
\text { Interface (in.) }\end{array}$ & $\begin{array}{c}\text { Wall to Wall } \\
\text { Interface (in.) }\end{array}$ \\
\hline ARMS & Coated brick wall & $4^{\mathrm{a}}$ & 3.5 & $6.5^{\mathrm{a}}$ \\
\hline LTC 1072Pn & Coated concrete ceiling & 0 & - & - \\
\hline WallWallker & Coated brick wall & $44^{\mathrm{b}}$ & 12 & 38 \\
\hline
\end{tabular}

- Not applicable

a Removal gap was due to containment structure.

b No ceiling existed on this particular test site. This removal gap was mainly due to the monorail mounting system, which supported the scabbler head.

\subsubsection{Aggressive Removal}

Three technologies were evaluated for aggressive removal of masonry wall surfaces. Table 2 presents a summary of the average depth of removal and its standard deviation attained by each of the aggressive technologies tested on the various surfaces. Figure 2 displays the production rates of these technologies in square feet per hour. Table 3 presents the removal gaps observed during evaluations. The most appropriate technology for a particular project and site may be selected based on its site-specific need and the integration of many factors (e.g., production rate, cost, health and safety, and secondary waste generation).

Table 2.

Depth of removal for aggressive removal technologies on masonry wall surfaces

\begin{tabular}{|l|l|c|c|}
\hline Technology & Surface type & $\begin{array}{c}\text { Removal depth and standard } \\
\text { deviation (in.) }\end{array}$ & $\begin{array}{c}\text { Removal depth specified by } \\
\text { vendor (in.) }\end{array}$ \\
\hline \multirow{3}{*}{ EBE 250 VHC } & Coated brick wall & $0.25^{\mathrm{a}}$ & 0.25 \\
\cline { 2 - 4 } & Coated concrete wall & $0.25^{\mathrm{a}}$ & 0.25 \\
\cline { 2 - 4 } & Uncoated concrete wall & $0.25^{\mathrm{a}}$ & 0.25 \\
\hline \multirow{2}{*}{ LTC 1072Pn } & Coated brick wall & $0.039 \pm 0.065^{\mathrm{b}}$ & 0.25 \\
\cline { 2 - 4 } & Uncoated concrete wall & $0.190 \pm 0.122^{\mathrm{b}}$ & 0.25 \\
\hline WallWalker & Coated concrete wall & $0.145 \pm 0.142^{\mathrm{b}}$ & 0.25 \\
\hline
\end{tabular}

a Determined by visual measurements.

b Determined by professional surveys. Example: $0.190 \pm 0.122 \mathrm{in} .0 .190 \mathrm{in}$. indicates the average removal depth, and 0.122 in. represents the roughness of the finished surface. 


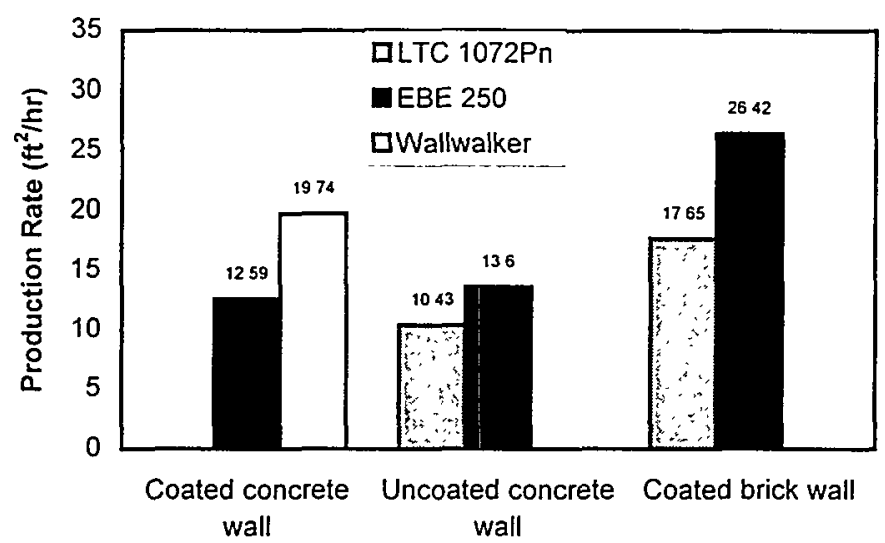

Figure 2. Production rates achieved by aggressive surface removal technologies on masonry walls.

Table 3.

Average removal gaps for aggressive removal technologies on masonry wall surfaces

\begin{tabular}{|c|l|c|c|c|}
\hline Technology & \multicolumn{1}{|c|}{ Surface type } & $\begin{array}{c}\text { Ceiling To Wall } \\
\text { Interface (in.) }\end{array}$ & $\begin{array}{c}\text { Floor to wall } \\
\text { interface (in.) }\end{array}$ & $\begin{array}{c}\text { Wall to wall } \\
\text { interface (in.) }\end{array}$ \\
\hline \multirow{2}{*}{ EBE 250 VHC } & Coated brick wall & $27^{\mathrm{a}}$ & 25 & 14 \\
\cline { 2 - 5 } & Uncoated concrete wall & $67^{\mathrm{a}}$ & 28 & 24 \\
\cline { 2 - 5 } & Coated concrete wall & $68^{\mathrm{a}}$ & 35 & 31 \\
\hline \multirow{2}{*}{ LTC 1072Pn } & Coated brick wall & $0^{\mathrm{b}}$ & - & 1.1 \\
\cline { 2 - 5 } & Uncoated concrete wall & $0^{\mathrm{b}}$ & 0 & 0 \\
\hline \multirow{2}{*}{ WallWalker } & Coated concrete wall & $41^{\mathrm{c}}$ & 9 & 39.5 \\
\hline
\end{tabular}

Not measured. The technology could not complete demonstration due to inclement weather.

a This removal gap was mainly due to the forklift configuration, which supported the shot blaster.

b No ceiling existed on this particular test site.

c This removal gap was mainly due to the monorail mounting system, which supported the scabbler head.

\subsection{SURFACE REMOVAL FROM CONCRETE FLOORS}

\subsubsection{Coating Removal}

During FY98, two technologies were evaluated for coating removal on concrete floors. Oceaneering International's $\mathrm{ROVCO}_{2}$ system encountered a long downtime during the demonstration due to major equipment breakdowns. It was not effective in removing all primer coating from concrete floor, and the production rate was only $1.1 \mathrm{ft}^{2} / \mathrm{hr}$.

Surface Technology Systems' ARMS ${ }^{\mathrm{TM}}$ managed to remove most coating from a concrete floor with a few patches of primer epoxy polyamine paint remaining on the floor at a rate of $26 \mathrm{ft}^{2} / \mathrm{hr}$. 
The removal gap for the technology was approximately 6 in. due to the configuration of the containment used.

\subsubsection{Aggressive Removal}

EBE 350 and Marcrist DTF25 Floor Shaver were demonstrated by Pegasus International for aggressive removal on concrete floors. In addition, Pentek demonstrated the Squirrel ${ }^{\circledast}$ III floor scabbler as a baseline decontamination technology. Table 4 summarizes the average depth of removal achieved by these technologies. Figure 3 presents a visual comparison of these technologies on their production rates. Again, the most appropriate technology for a particular project and site must be determined by the integration of many factors with the consideration of the site-specific needs.

Table 4.

Depth of removal for aggressive removal technologies on the concrete floors

\begin{tabular}{|l|l|c|c|}
\hline \multicolumn{1}{|c|}{ Technology } & Surface type & $\begin{array}{c}\text { Removal depth and } \\
\text { standard deviation* (in.) }\end{array}$ & $\begin{array}{c}\text { Removal depth specified } \\
\text { by vendor (in.) }\end{array}$ \\
\hline \multirow{2}{*}{ EBE 350 } & Uncoated concrete floor & $0.336 \pm 0.060$ & 0.25 \\
\cline { 2 - 4 } & Coated concrete floor & $0.324 \pm 0.037$ & 0.25 \\
\hline \multirow{2}{*}{$\begin{array}{l}\text { Marcrist DTF25 } \\
\text { Floor Shaver }\end{array}$} & Uncoated concrete floor & $0.228 \pm 0.020$ & 0.50 \\
\cline { 2 - 4 } & Coated concrete floor & $0.324 \pm 0.034$ & 0.50 \\
\hline \multirow{2}{*}{ Squirrel III } & Uncoated concrete floor & $0.192 \pm 0.072$ & 0.25 \\
\cline { 2 - 4 } & Coated concrete floor & $0.144 \pm 0.06$ & 0.25 \\
\hline
\end{tabular}

* Determined by professional surveys. Example: $0.336 \pm 0.060$ in. 0.336 in. indicates the average removal depth, and $0.060 \mathrm{in}$. represents the roughness of the finished surface.

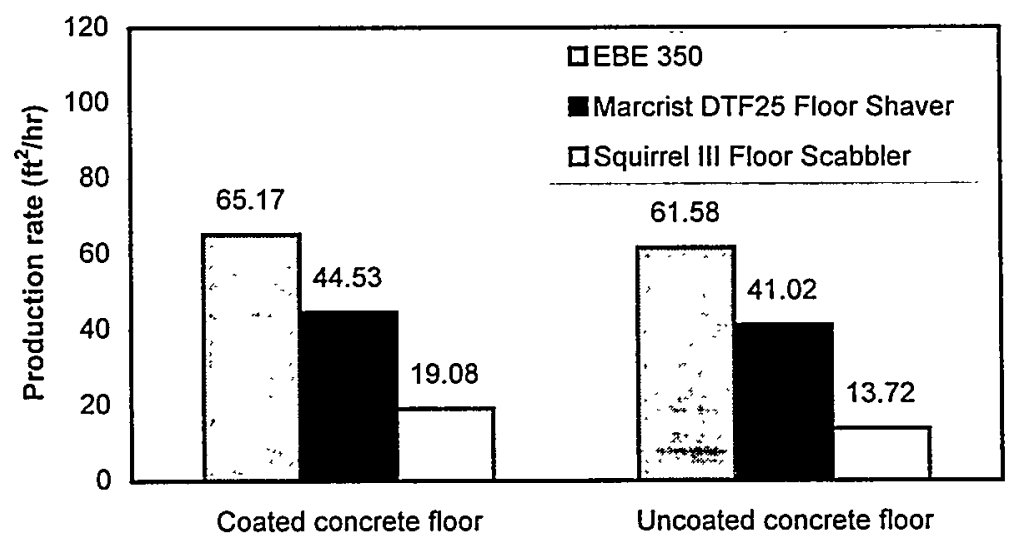

Figure 3. Production rates achieved by aggressive removal technologies on concrete floors. 
Table 5.

Average removal gaps for aggressive removal technologies on concrete floors

\begin{tabular}{|c|c|c|c|}
\hline Technology & EBE 350 & Marcrist DTF25 Floor Shaver & Squirrel $^{\circledR}$ III \\
\hline Floor to wall interface (in.) & 3 & 6 & 0.7 \\
\hline
\end{tabular}

\subsection{HEALTH AND SAFETY RESULTS}

Representatives of the International Union of Operating Engineers (IUOE) collected health and safety related data during the technology demonstrations. Factors such as dust level, noise level, heat stress, tripping hazards, electrical hazards, machine guarding hazards, struck-by hazards, ergonomics, and laceration hazards were evaluated throughout the technology assessments. A summary of the dust and noise levels reported in the IUOE Human Factors Assessment Draft Reports is exhibited in Appendix D. The reports can be obtained from IUOE, National Hazmat Program:

Mail: $\quad$ Operating Engineers National Hazmat Program
1293 Airport Road
Beaver, WV 25813
Attention: Barbara McCabe

Fax: $\quad$ (304) $253-1384$

Email:_bmccabe@iuoeiettc.org

\subsection{MISD ACCOMPLISHMENTS}

The principal objectives of MISD are to manage technology assessment data and provide D\&D decision-makers with objective, comparable cost and performance evaluations of decontamination technologies. One of FIU-HCET's goals is to become a Center for Excellence for D\&D technology information. By assimilating reliable technology assessment data into a single source and making it accessible via the Internet, FIU-HCET will provide remediation site managers with a powerful tool for expediting selection of decontamination technologies. During FY98, significant progress was made toward accomplishing this goal. One of the major accomplishments was the enhancement and implementation of the MISD database on the Internet. This database will allow FIU-HCET personnel to input technology assessment data from any Internet-accessible location. During the first quarter of 1999, data retrieval features will be developed that will allow users to perform queries and generate reports from the MISD system over the Internet.

Table 6 summarizes the status of MISD as of the end of the fiscal year on October 31, 1998, of the tasks that were identified for completion in FY98 in connection with the development of the MISD. These tasks were defined in the FY98 Project Technical Plan Decision Analysis and Technology Assessments for Metal and Masonry Decontamination Technologies and were aimed at planning and managing the work activities for the project. Descriptions of these tasks and accomplishments are provided below. 
Table 6.

Status of project technical plan for multimedia system

\begin{tabular}{|l|l|}
\hline Task & Status as of October 31, 1998 \\
\hline Performance data acquisition & Completed \\
\hline Entry of technology assessment data into MISD & Ongoing \\
\hline Develop the MISD in SQL-Server & Completed \\
\hline Redesign and improve the MISD database & $\begin{array}{l}\text { Phase I Complete } \\
\text { Phase II In Progress }\end{array}$ \\
\hline
\end{tabular}

1) Performance Data Acquisition

Task: To perform a search to determine some existing and developing information systems that contain performance data for metal and masonry decontamination technologies.

Status: Completed.

FIU-HCET has received from DOE a database of D\&D technologies and will be integrating these into MISD. Reliable technology assessment information from other sources is being pursued for possible inclusion in MISD.

2) Entry of Technology Assessment Data into the MISD

Task: Technology assessment data needs to be incorporated into the MISD. Two to three assessment photographs that best display the technology tested or a brief video of technology needs to be digitally scanned and entered into the MISD database.

Status: Ongoing.

Technology assessment data are currently being entered into the MISD. Photographs and/or video clips that illustrate operation of the technology tested will also be integrated into the database.

\section{3) Develop the MISD in SQL-Server}

Task: In order to meet the software requirements necessary to integrate the MISD with the decision analysis software application and to implement the MISD on the Internet, the system had to be developed in a higher level platform.

Status: Completed.

FIU-HCET developed the tables and relationships for the MISD database in SQL-Server 6.5. This platform was selected because of its ability to handle digital photographic and video images.

4) Redesign and Improve the MISD Database

Task: Analyze, re-design, and improve the MISD database.

Status: Phase I Completed.

Phase II In Process. 
The MISD access database was upgraded to Microsoft SQL-Server, redesigned and made accessible via the Internet. The MISD system was planned for development in two phases. The first phase was to implement the database on the Internet for FIU-HCET's data entry personnel to input the data on the technology assessments. The second phase was to implement a web site connected to the MISD database to allow authorized users to perform queries and generate reports. Phase 1 was completed in FY98, and Phase 2 will be completed in FY99.

\subsection{DASD ACCOMPLISHMENTS}

DASD is a powerful analytical tool that allows D\&D project managers to define their sitespecific decontamination needs and then searches the MISD database of D\&D technologies to identify the most suitable solutions. DASD is being designed to be the main analytical and computational tool for assessing D\&D project parameters and recommending viable technology solutions. The goal is to provide remediation site managers with a tool that significantly reduces the time required to search for and select appropriate technological solutions from an information repository of proven innovative and baseline technologies. During FY98, FIU-HCET completed the design of the DASD and made significant progress toward accomplishing this goal; however, planned linkages to the MISD database could not be completed due to the upgradings of that system that were underway. For FY99, the DASD system will have full connection capabilities to the MISD database and have an online Help system. System enhancements will also be implemented, and distribution of the final product will be completed in FY99.

Major accomplishments on the development of DASD are summarized below. Further explanation of these accomplishments is provided in subsequent paragraphs.

- Completion of the prototype of the DASD software application

- Distribution of the prototype of the DASD software application at the X-Change ' 97 conference held in Miami, Florida, in December 1997

- Implementation some of the enhancements suggested by the D\&D professionals who evaluated the prototype of the DASD software.

\subsubsection{Completion of the Prototype of the DASD Software Application}

The development of the prototype DASD software application was completed in FY98 and contains the standard features required to screen and evaluate technologies. The prototype version contains data pertaining only to concrete floor coating-removal technologies. Additional problem sets will be added in FY99. 


\subsubsection{Distribution of the Prototype Software Application. Implementation of the enhancements suggested by D\&D professionals}

The prototype DASD software application was completed in FY98 and demonstrated at the X-Change' 97 conference held in Miami, Florida, in December 1997. D\&D professionals attending the conference provided invaluable feedback on the functionalities of the system and enhancements they would like to see incorporated into the final release. Some of these suggestions, including a historical user database and screen image enhancements, have already been incorporated, and others will be included during FY99. 


\subsection{ENGINEERING STUDY APPROACH}

\subsection{STUDY OBJECTIVES}

The objective of this study was to perform a comparative analysis of commercially available and innovative surface removal technologies applicable to the metal and masonry structures at nuclear or hazardous facilities.

\subsection{EXPERIMENTAL DESIGN AND PROCEDURES}

\subsubsection{Selection of Technologies for this Study}

Potential vendors and technologies were identified by means of 1) placing a Commerce Business Daily (CBD) advertisement; 2) Internet search; 3) word of mouth; 4) conferences and forums; and 5) professional journals. Bidders were selected based on their work experience in nuclear decontamination, technology capabilities, and references of previous technology demonstrations. Considering these criteria, the following innovative and commercially available technologies were evaluated at FIU-HCET in FY98:

- $E B E 250 \mathrm{VHC}$ vertical shot blaster [commercial]

- $E B E 350$ floor shot blaster [commercial]

- Remote Operated Vehicle with $\mathrm{CO}_{2}\left(\mathrm{ROVCO}_{2}\right)$ [innovative]

- WallWalker ${ }^{\mathrm{TM}}$ [innovative]

- Marcrist DTF25 Floor Shaver [commercial]

- LTC 1072Pn Grit Blaster [commercial]

- Advanced Recyclable Media System $\left(A R M S^{\mathrm{rN}}\right)$ [commercial]

- Squirre III Floor Scabbler [commercial].

Among these technologies, WallWalker ${ }^{\mathrm{TM}}$, ARMS $^{\mathrm{Tw}}$, and LTC $1072 \mathrm{Pn}$ were evaluated at FIUHCET between FY95 and FY97. However, during the past several years, each technology has undergone some modifications to improve technology performance. For example, WallWalker ${ }^{\mathrm{TM}}$ demonstrated in FY98 used a new monorail mounting system and a more aggressive scabbler head. LTC 1072Pn utilized a newly designed filtration system to improve productivity and an articulating arm to reduce operator fatigue. Details about these technologies can be found in Section 4.0 of this report, Technology Descriptions. 


\subsubsection{FIU-HCET Technology Assessment Site}

The FIU-HCET technology assessment site is located on FIU's campus in Miami, Florida. The site and its schematic are shown in Figures $4 \mathrm{a}$ and $4 \mathrm{~b}$. Each test bay consists of a concrete pad with approximately 10-foot-high concrete or brick walls on three sides and, in some bays, a concrete ceiling covering half of the pad. The concrete walls have a compressive strength of between 4,240 and 6,370 psi, and the concrete floors have a compressive strength of between 4,420 and 5,660 psi. All concrete walls, floors, and ceilings at the assessment site have a thickness of 8 inches. The brick walls (approximately 4 inches of thickness) were built onto the concrete walls after the concrete walls were poured. Each floor test surface measures approximately $20 \mathrm{ft}$ by $20 \mathrm{ft}$ to yield an area of approximately $400 \mathrm{ft}^{2}$. Each wall and ceiling test surface measures approximately $20 \mathrm{ft}$ by $10 \mathrm{ft}$ to yield an area of approximately $200 \mathrm{ft}^{2}$. All technology demonstrations were performed outdoors, exposed to various weather conditions, with the exception of the ceiling that covers a portion of some of the test bays. Each technology was evaluated based on its performance over the selected test surfaces.

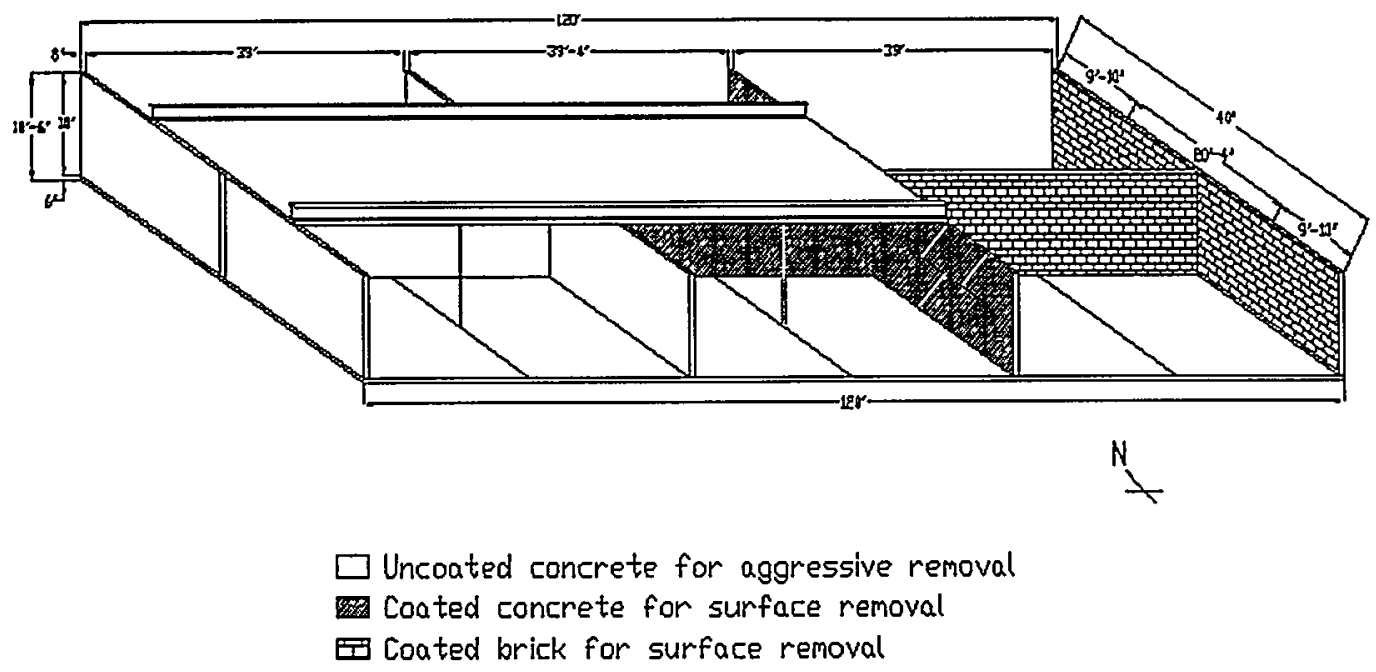

Figure 4a. FIU-HCET technology assessment site schematic. 


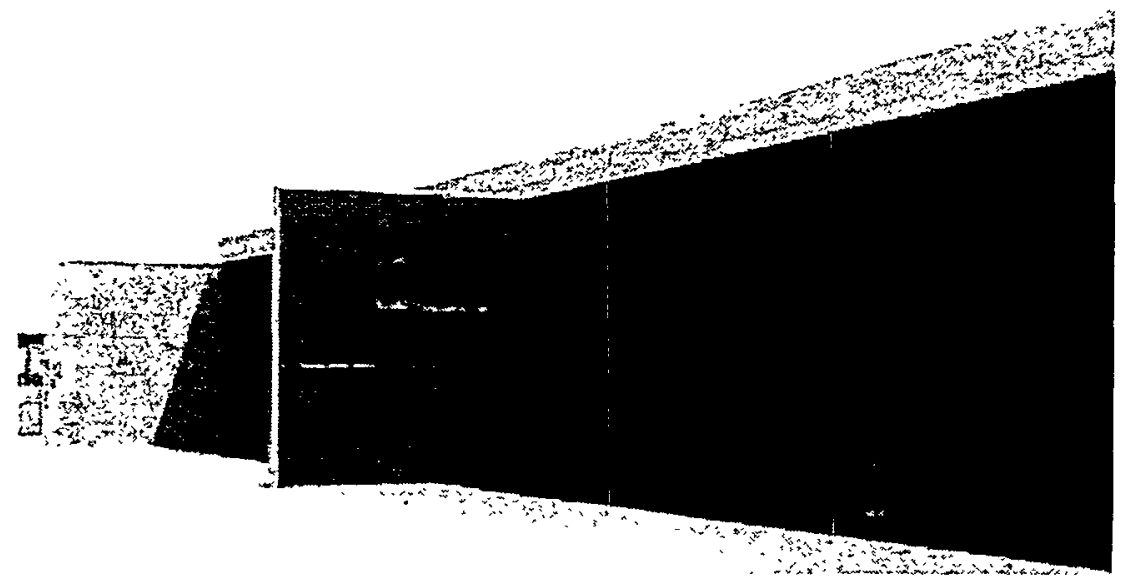

Figure 4b. FIU-HCET technology assessment site. Note the coated concrete wall (foreground) and uncoated concrete wall (background).

The FIU-HCET technology assessment site is surrounded by a 6-foot-tall chain link fence to provide security and to restrict access to the area. Adjacent to the assessment site test pads there is a trailer and an air-conditioned metal shed, which serve as field office, changing facility, and cooldown area for the technology vendor crew, the FIU-HCET technology assessment team, and IUOE representatives. An additional metal shed (non-air-conditioned) is available for use during technology demonstrations on the metal surface media. During technology assessments, each test bay was covered by a tent with three side walls to serve as a wind buffer and sun shield.

\section{Masonry Surface Media}

A preliminary review of the facilities of the Fernald Environmental Management Project (FEMP) and other DOE remediation sites indicated wide variability in the composition and types of concrete used when these facilities were constructed. This variability was taken into consideration during the selection of the proper mix design for the construction of the FIU-HCET concrete test areas. Based on this review, a 4000-psi mix was specified that incorporated a limestone aggregate material.

During construction of the walls, snap ties were used every two to three feet to hold the forms together that shaped each wall. Standard rebar (steel bars) was used to hold, shape, and strengthen the poured concrete. After the concrete was set, the forms were removed, leaving the snap ties exposed on the surface of the concrete walls. The majority of the snap ties were cut as deep as 1 inch into the surface of the wall, although some were cut closer to the surface. The holes in the wall were then patched with concrete. It is possible that aggressive surface removal technologies could encounter several shallowly cut snap ties during treatment of the concrete walls. 


\section{Metal Surface Media}

The carbon steel plates used for this study were $4 \mathrm{ft}$ by $4 \mathrm{ft}$ by $1 / 4$ inch thick. A surface condition designation for each piece of finished metal media was assigned immediately following its completion, based on the guidelines of the Steel Structures Painting Council (SSPC).

\section{Coating Specifications}

The determination of the appropriate coatings to be used for FIU-HCET's technology assessments wàs made using FEMP's paint specifications for acid-resistant surfaces. The masonry surface media were prepared according to the Michael A. Bruder \& Son technical data and application instructions. A Ply-Mastic epoxy polyamine coating primer was applied to selected concrete floors, walls, ceilings, and brick walls at 8 mils wet to obtain 7 mils dry film thickness. After 24 hours, a finish coating of Ply-Thane 890 HS was applied at 3 mils wet to obtain $1 \frac{1}{2}$ mils dry film thickness. The estimated total thickness of the primer and the finish coats is $81 / 2$ mils dry film thickness.

The metal surface media were prepared according to the Michael A. Bruder \& Son technical data and application instructions. For the carbon steel plates, a Ply-Mastic epoxy polyamine coating primer was applied at 8 mils wet to obtain 7 mils dry film thickness. After 24 hours, a finish coating of Ply-Thane $880 \mathrm{HS}$ was applied at 3 mils wet to obtain $1 \frac{1}{2}$ mils dry film thickness. The estimated total thickness of the primer and the finish coats is $81 / 2$ mils dry film thickness.

\subsection{TECHNOLOGY ASSESSMENT DATA COLLECTION}

FIU-HCET evaluators were present at all times for the duration of the technology demonstration to record performance data and to take photographs and video during the technology's operation.

\subsubsection{Health and Safety Monitoring}

Health and safety monitoring was conducted during the technology demonstration by the representatives of the IUOE.

Dust level - Samples of airborne dust released during technology operation were collected during the tests. Personal dust exposure to the equipment operator was measured according to standard National Institute for Occupational Safety and Health (NIOSH) methods for total and respirable dust. The samples were analyzed gravimetrically by an American Industrial Hygiene Association (AIHA)-accredited lab. Dust released to the environment was measured with higher volume samplers placed within the test area.

Noise level - Sound pressure levels were measured during technology operation and those frequencies posing the greatest risk to the worker were identified. Personal operator exposure readings were collected in addition to readings taken at a distance of $10 \mathrm{ft}$.

Other safety and health issues - Heat stress, tripping hazards, electrical hazards, machine guarding hazards, struck-by hazards, ergonomics, and laceration hazards were also evaluated throughout technology operation. 
Other safety and health issues - Heat stress, tripping hazards, electrical hazards, machine guarding hazards, struck-by hazards, ergonomics, and laceration hazards were also evaluated throughout technology operation.

\subsubsection{Data Collection}

FIU-HCET evaluators collected data throughout each technology demonstration by direct measurements/observations, querying the vendor, and/or outside reference sources. Appendix A provides a complete list of data types, data definitions, and expected method(s) of collection.

\section{Professional Survey}

Depth of removal achieved by any aggressive surface removal technology was determined by certified professional surveyors, whenever available. Surveyors used in FY98 were Biscayne Engineering Company, Inc., and James Beadman \& Associates, Inc., both of which are located in Miami, Florida. Two independent measurements were conducted, one prior to demonstration and the other after. The survey points were aligned using a 1-foot grid spacing. Difference between the two measurements was used to determine the depth of removal. Only the points that had undergone aggressive surface removal were used to calculate the average depth of removal. The accuracy of the surveying instruments was better than 0.0625 inch. 


\subsection{TECHNOLOGY DESCRIPTIONS}

\subsection{SURFACE REMOVAL FROM METAL PLATES}

\subsection{1 $\mathrm{ROVCO}_{2}$}

$\mathrm{ROVCO}_{2}$ is a remotely operated vehicle $\mathrm{CO}_{2}$ blasting system. The system shoots pellets of dry ice propelled by high pressure air at the surface being cleaned. At the moment of impact, the dry ice pellets fracture and remove a layer of the contaminated surface. The pellets then turn to a gaseous state, which is vacuumed away by a built-in vacuum system with the debris of removed surface. Figure 5 shows $\mathrm{ROVCO}_{2}$ 's operation on a coated steel plate. The system is equipped with a front and a rear camera and is connected by a tether to the control station where operators can adjust the operation of the blast nozzle and the movement of the vehicle.

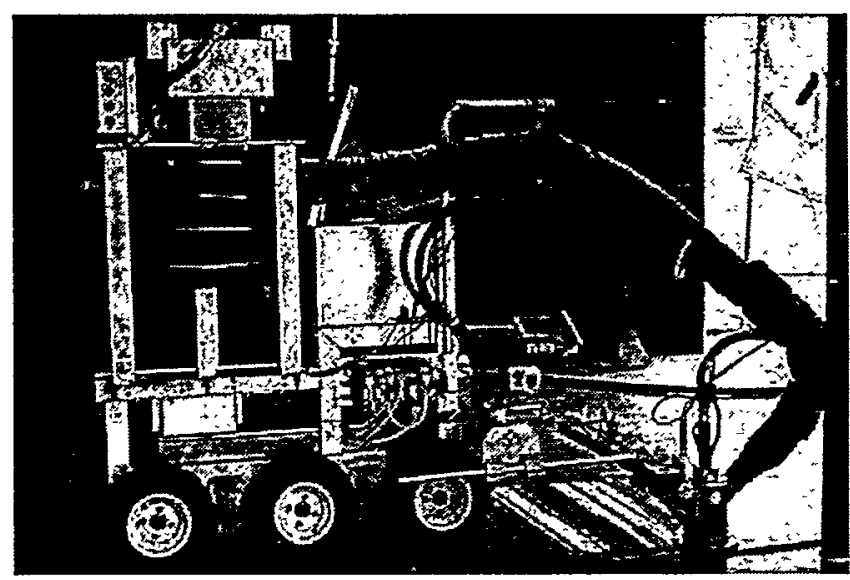

Figure 5. $\mathrm{ROVCO}_{2}$ performing coating removal on a steel plate.

\subsection{SURFACE REMOVAL FROM MASONRY WALLS AND CEILINGS}

\subsubsection{Advanced Recyclable Media System (ARMS ${ }^{\text {TM }}$ )}

As shown in Figure 6, the $\mathrm{ARMS}^{\mathrm{TM}}$ equipment is comprised of a feed unit and a sifter unit. The feed unit is a portable pneumatically powered device that propels the sponge media against the contaminated surface. Sponge media is manually loaded into a hopper mounted on top of the feed unit and is fed to an auger device that mixes the cleaning media with compressed air. The media is then transported through the standard abrasive blasting hose and the blasting nozzle to the surface being removed. The sifter unit mechanically removes large debris and powdery 
residues from the sponge media after use. The sifter vibrates causing the media to fall downward through a series of separation screens to remove the debris from the recyclable media. The soft media used was aluminum oxide fiber, Type B. This media was highly absorptive and was capable of capturing, absorbing, and removing a variety of surface contaminants.

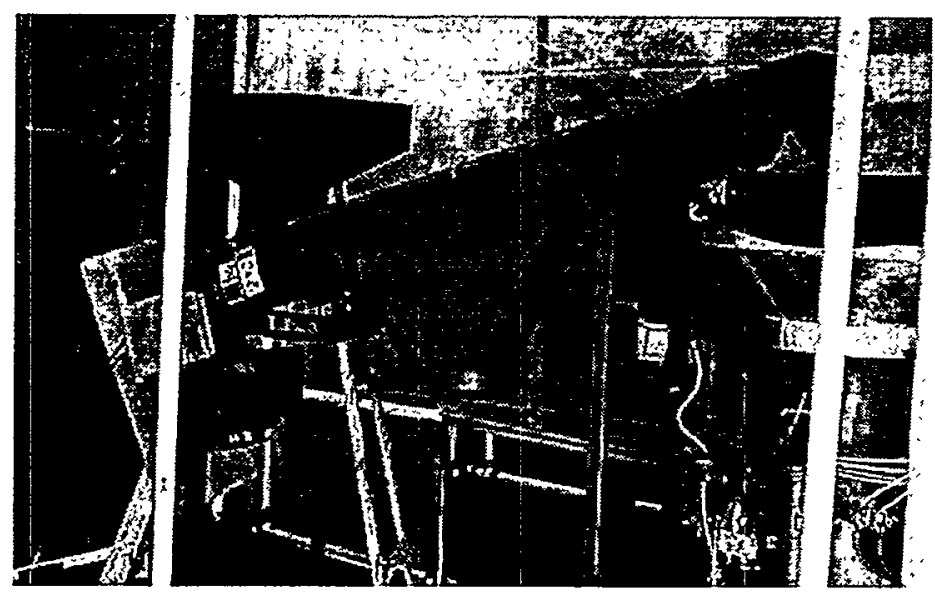

Figure 6. ARMS ${ }^{T M}-A$ sponge blast system.

\subsubsection{EBE 250 VHC}

The EBE $250 \mathrm{VHC}$ is a remotely operated shot blasting system designed to operate on vertical surfaces. It consists of two main units. One is a self-propelled blast head, which blasts the contaminated surface with abrasive, and the other is a remote vacuum unit (EBE 250DA), which collects the dust, debris, and the spent media. Debris is separated from the abrasive within the machine on a continuous basis: separated abrasive is reused, debris is transported to the dust collector. Figure 7 presents the operation of EBE 250 VHC on a coated brick wall. 


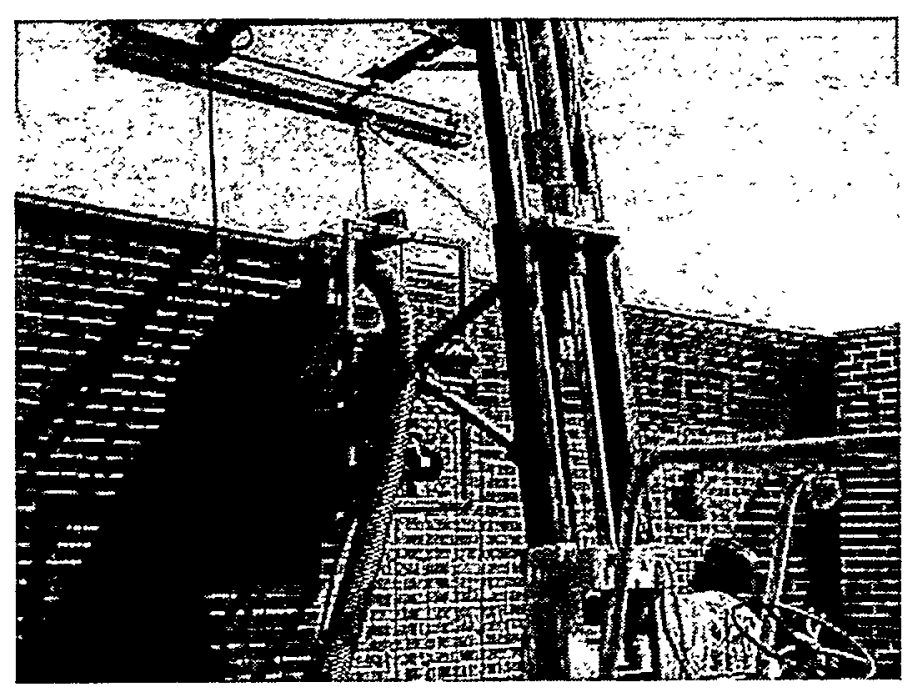

Figure 7. EBE 250 VHC operating on a coated brick wall.

\subsubsection{WallWalker ${ }^{\text {TM }}$}

An older version of this innovative robotic scabbling technology was evaluated at FIU-HCET in fiscal year 1997. Over the past year, additional development has taken place, partially resulting from the experience and lessons learned during FIU-HCET demonstration. The new WallWalker $^{\mathrm{TM}}$ system used a monorail mounting system, as shown in Figure 8, attempting to operate over two or three connecting walls, without repositioning the support mechanism after initial installation. Thus, the production rate is improved by reducing setup time for system repositioning.

In addition to the mounting system, the system consists of three other major subsystems: a motion control subsystem, a heavy-duty scabbler work head, and an ultra-high performance vacuum system.

The heart of the motion control subsystem is the system controller and operating software. The WallWalker $^{\mathrm{TM}}$ system can be configured with a variety of controllers. The current system utilizes an IBM ThinkPad laptop computer and a Windows 95-based program.

The operating software allows the user to control the work head's position and define its path of movement. The scabbler head can be "steered" using a manual up-down-left-right movement or can be moved along a predefined path (e.g., straight line, horizontal raster pattern, circle).

The scabbler head contains three single-piston scabblers mounted on an independent suspension. The scabbler head demonstrated in FY98 was more powerful than the one used in FY97. The diameter of scabbler bits has been increased from $13 / 8$ in. to $21 / 4$ inch. To provide an even surface profile, the three scabblers can be rotated.

Pentek's VAC-PAC was used as a vacuum system. The VAC-PAC contains pre-filters and a HEPA filter. The VAC-PAC features automatic self-cleaning of the pre-filters using reverse-flow 
pulses of high pressure air, a feature that eliminates filter clogging and allows for continuous vacuuming without interruptions or operator exposure due to filter replacement.

Another improvement over the FY97 version was that two important safety features have been incorporated in the positioning trolleys. First, there is a solenoid-controlled brake pin on each trolley to ensure that it remains fixed in position during operations. The brake pins are controlled using an $\mathrm{AC}$ voltage and can be engaged and disengaged using a toggle switch on the scabbler control unit. The trolleys also incorporate proximity switches to ensure that the brake pin is fully engaged.

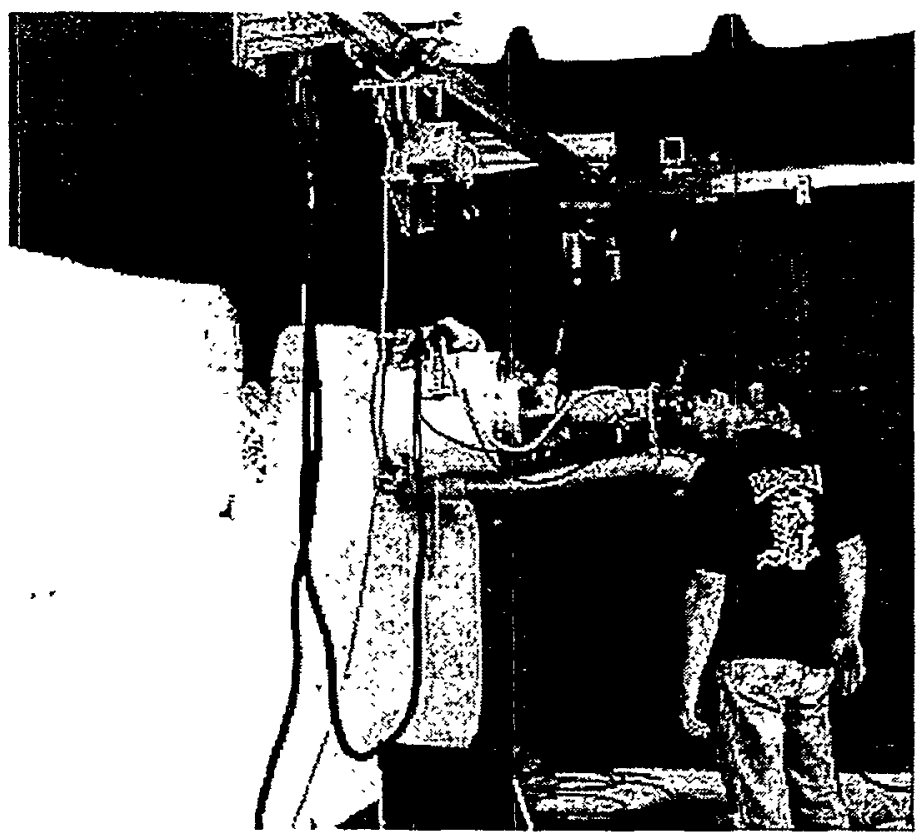

Figure 8. WallWalker operating on coated concrete wall.

\subsubsection{LTC 1072Pn}

This grit blasting technology was evaluated for coating removal on metal surfaces at FIU-HCET in FY95. Over the past year, LTC Americas has developed a new filter cleaning system, so called "Concrete Filter Cleaning Valve" (CFCV). Using CFCV, an LTC 1072Pn could reduce downtime by blasting for longer periods before stopping to clean the filters. The new filtration system also allows the blast pressure to increase by $50 \%$, which also results in improved productivity. In addition, the new LTC 1072Pn blasting was coupled with an articulating arm and floor trolleys (shown in Figure 10). With the articulating arm, operators can move a large blast head with ease, which considerably reduced operator fatigue. 
The LTC 1072Pn is a grit blasting machine with a dual nozzle capability. This machine works on the principle of dry abrasive blasting and a mechanism of simultaneous recovery of the abrasive and the waste generated.

This technology is configured with a compressor linked to cooler dryer unit, which in turn is linked to the machine. The air requirement for the LTC $1072 \mathrm{Pn}$ technology is $1300 \mathrm{cfm}$ at 150 psi. The LTC 1072Pn consists of a dual pressure chamber vessel, two vacuum generators (each having a built-in venturi), two primary filters, an optional HEPA filter, and a scaled half drum for dust-free waste disposal.

Additionally, this technology can be linked to optional electronic controls that would allow automatic shutdown at individual blast heads during the blasting operation, if the blast head were accidentally displaced away from the surface or if the differential pressure across the filters exceeded the programmed maxima.

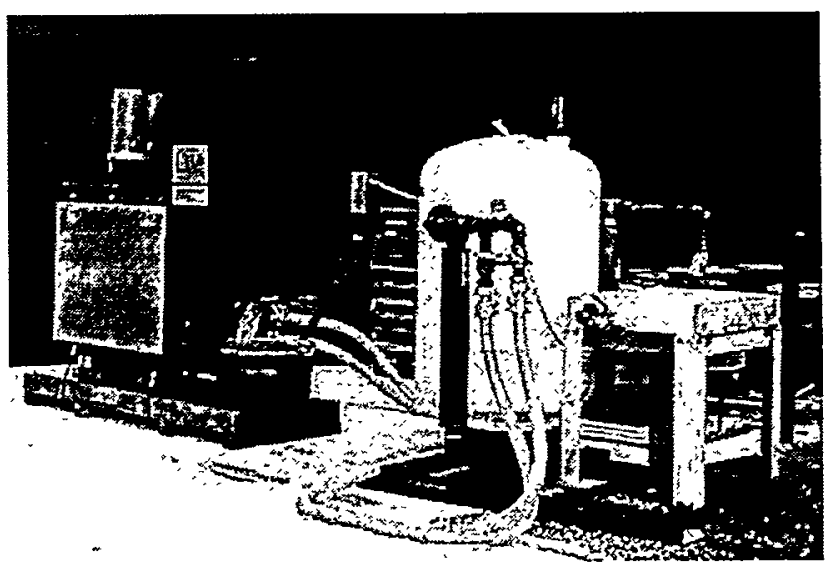

Figure 9. LTC 1072Pn and LTC Air Cooler/Dryer.

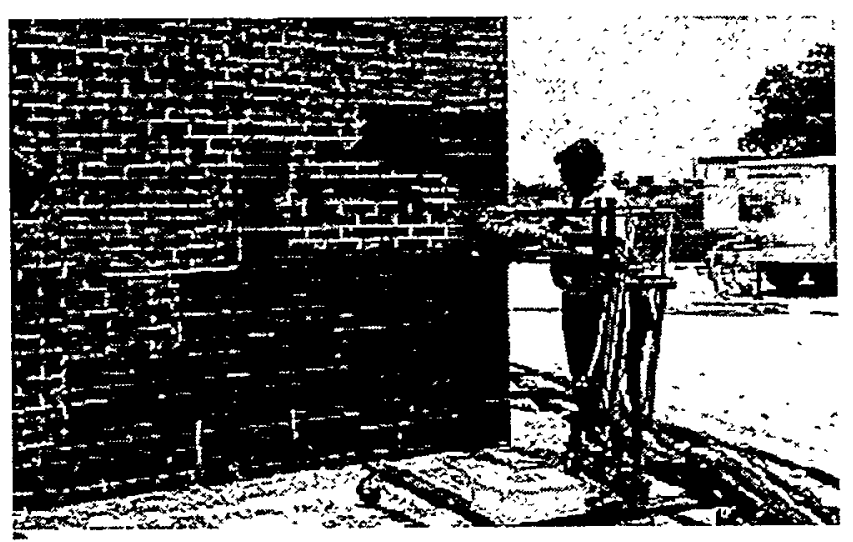

Figure 10. LTC Americas' operator decontaminating a coated brick wall using the articulating arm. 


\subsection{SURFACE REMOVAL FROM CONCRETE FLOORS}

\subsection{1 $\mathrm{ROVCO}_{2}$}

See section 4.1.1 for technology description. Figure 11 displays $\mathrm{ROVCO}_{2}$ 's operation on a coated concrete floor. As can be seen, some primer coating could not be removed by this system.

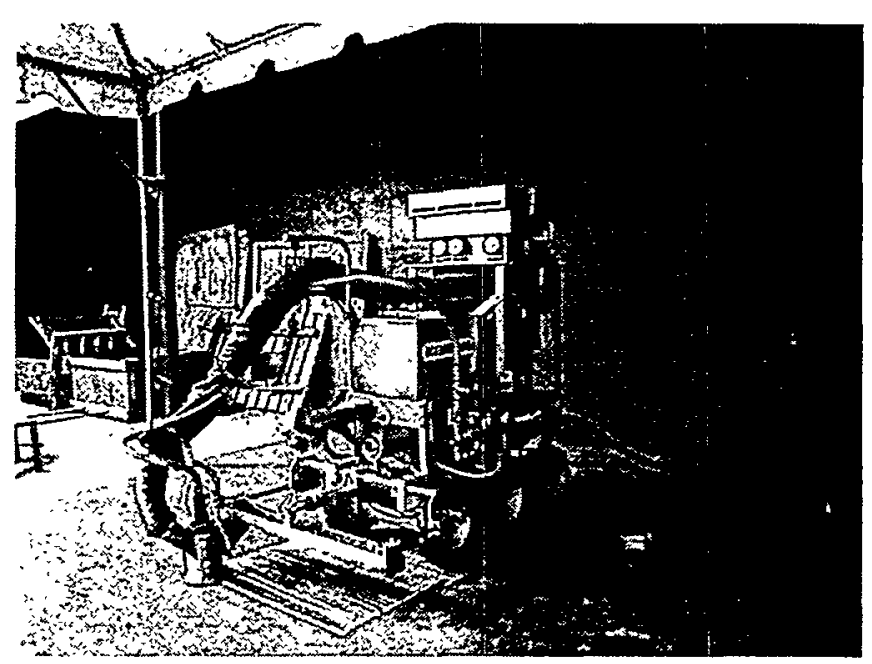

Figure 11. $\mathrm{ROVCO}_{2}$ in operation removing coating from a concrete floor.

\subsubsection{EBE 350}

This is another blasting system manufactured by the European Blastcleaning Equipment Company. Similar to the EBE $250 \mathrm{VHC}$, but designed to operate on horizontal surfaces, the EBE 350 consists of a self-propelled blaster connected to a vacuum unit for dust collection. The blast head releases abrasive at a high velocity to contaminated surfaces being cleaned. The abrasive and the material are mechanically reclaimed within the machine. The abrasive is then reused, and the debris is drawn into the vacuum system for collection and disposal. The dust collector is a separate unit that can be placed at up to $600 \mathrm{ft}$ away from the blast head. The dust collector includes a series of pulse jet-operated pre-filters and a HEPA filter. The dust is collected in the dust bin and later transferred to a 55-gallon drum for disposal. 


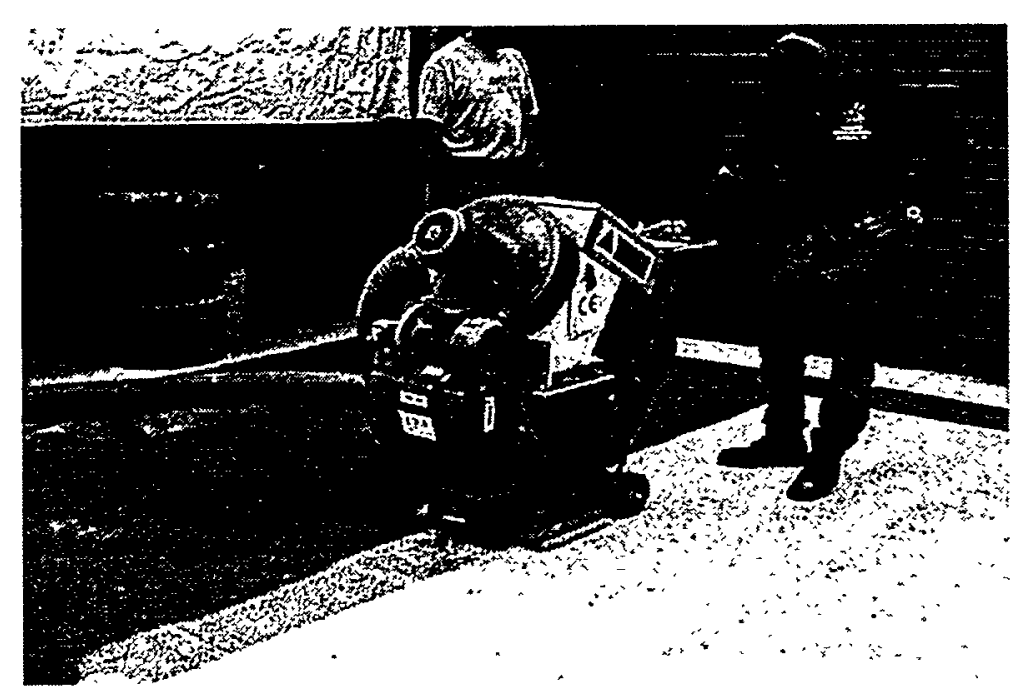

Figure 12. EBE 350 operating on a coated concrete floor.

\subsubsection{Marcrist DTF25 Floor Shaver}

The Marcrist DTF25 Floor Shaver is a self-propelled unit, which is capable of shaving a predetermined amount of concrete from structures by using diamond blades. The shaving diamond blades are mounted on a specially designed drum that rotates during operation. The waste material is collected via a dust shroud connected to a vacuum extraction system. The DTF25 is capable of shaving a $250 \mathrm{~mm}$ (9.8 in.) width and up to $15 \mathrm{~mm}(0.59 \mathrm{in}$.) depth with each pass. The system produces completely smooth finished surfaces, while no damage is conveyed to the surrounding material.

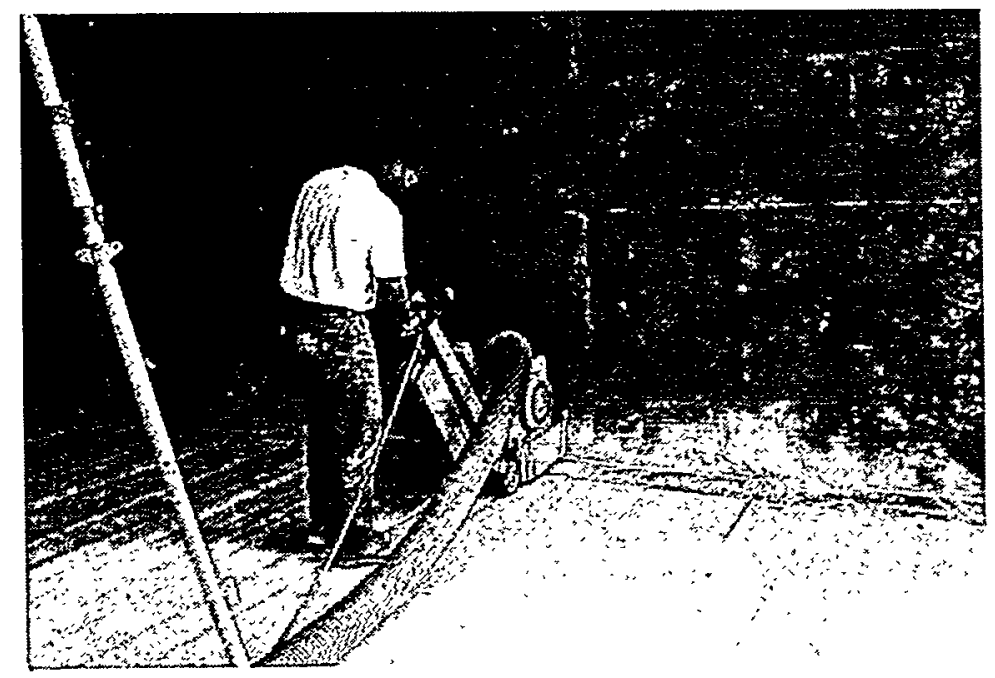

Figure 13. Marcrist Floor Shaver operating on a coated concrete floor. 


\subsubsection{Squirrel ${ }^{\circledR}$ III}

The Squirrel ${ }^{\mathbb{E}}$ III is a pneumatic-operated scabbler that operates in conjunction with an ultra-high performance HEPA-filtered vacuum system. Each Squirrel ${ }^{\mathbb{B}}$ III contains three 9-tooth Tungsten Carbide-Tipped Bits. The Squirrel ${ }^{B}$ III incorporates unique vacuum flow designs, which provide high efficiency performance in contaminated or clean-room environments that require stringent control of dust, debris, and airborne contamination. The Squirrel ${ }^{\circledR}$ III is designed to tackle small jobs and to get into tight places near corners, wall/floor joints, floor penetrations, steps, and under protruding equipment. The Squirrel ${ }^{\mathbb{B}}$ III is equipped with carrier wheels and a handle for easy transport around the job site (see Figure 14). It is also designed to remove protective coatings, laitance, and concrete substrate in a single step-process. Surfaces are left clean with a uniform texture and ready to receive new coatings.

The Squirrel ${ }^{\text {i }}$ III also incorporates Pentek's exclusive scabbling head vibration isolation technology, which drastically reduces operator fatigue associated with conventional scabbling equipment.

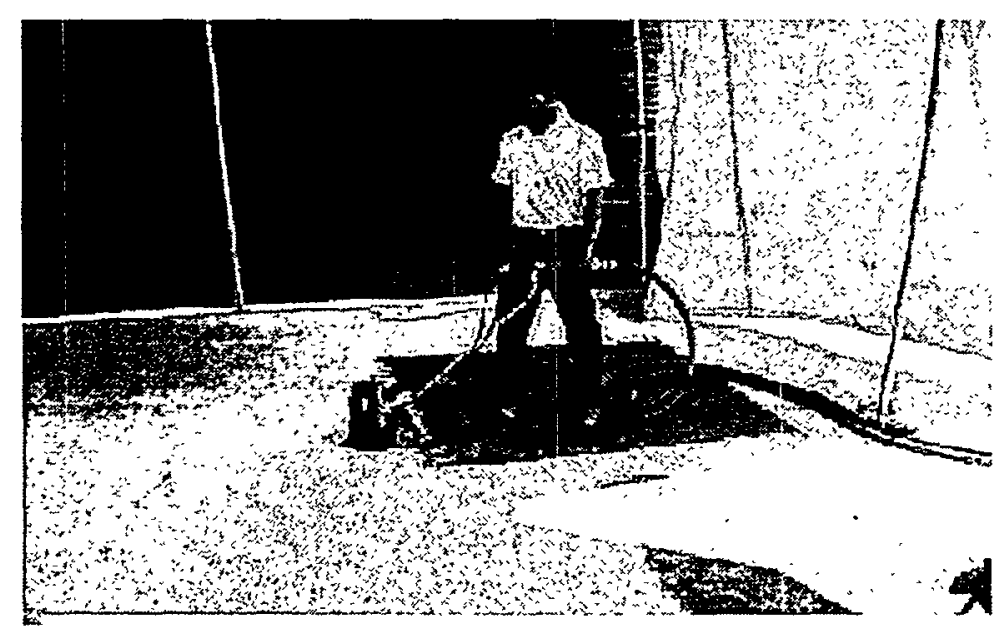

Figure 14. Squirrel ${ }^{\oplus}$ III operating on a coated concrete floor.

\subsubsection{ARMS $^{\text {TM }}$}

See Section 4.2.1 for technology description. 


\subsection{LESSONS LEARNED}

\subsection{TECHNOLOGY IMPLEMENTATION DEVIATIONS}

\subsubsection{LTC 1072Pn}

The system was expected to remove $1 / 4$ inch from the brick wall surface. However, because the mortar joint was softer than the brick, the abrasive tended to come out of the sides between the blast head and the mortar joints, thus restricting the equipment from achieving a better depth of removal.

In addition, due to heavy rain on the days prior and during the demonstration, the coated brick wall became very saturated with water at the very bottom of the wall. Therefore, an area of approximately 11.25 in. $\times 229.25$ in. could not be blasted because the moist recycled media and brick waste were clogging up the filters. Approximately $25 \%$ of the filter was blocked with wet brick powders soon after the operation began. The operators had to stop to clean filters more frequently thereafter.

Furthermore, the air compressors delivered to the evaluation site provide air pressure of only 110 psi instead of $150 \mathrm{psi}$, a designed air pressure.

\subsubsection{Marcrist Diamond Floor Shaver}

The vacuum system used by the vendor during the demonstration was not properly connected to the Marcrist unit. The diameter of the vacuum hose was considerably larger than the dust outlet on the floor shaver. Without a proper fitting being available, the hose was simply taped into place. This resulted in dust and debris being left on the floor and some becoming airborne. According to the manufacturer manual, it is essential to utilize a high-performance dust extraction system with this machine to achieve dust-free operation.

\subsubsection{Advance Recyclable Media System (ARMS ${ }^{\mathrm{nu}}$ )}

Although the ARMS ${ }^{\mathrm{TM}}$ successfully removed coating from the brick wall, the system operators stopped the concrete floor decontamination operations, leaving several patches of primer coating remaining on the floor surface. The operators stated that as STS began to remove the coatings on the floor, the primer coating was much thicker in some areas than it was on the wall. Where the areas were thinner, the technology removed coating down to the concrete. But for the thicker areas, the media was not aggressive enough. It was decided that it was not cost-effective to achieve $100 \%$ removal of the primer.

\subsubsection{WallWalker ${ }^{\text {nI }}$}

Pentek originally planned to demonstrate their technology for aggressive removal on brick walls. However, during the operation, large chunks of brick were often dislodged from the surface and 
became trapped between the scabbler head and the surface or in the vacuum intake. Each time this occurred, operators had to stop to remove the brick fragments before decontamination could continue. The operation was rather inefficient. Operators then decided to perform only coating removal on the brick walls.

\subsubsection{ROVCO}

During demonstration on coated steel plates, the technology was only able to reach the bare metal on an area of $2.12 \mathrm{ft}^{2}$. In the remainder of the removed area, the technology was only able to reach the primer paint.

The technology encountered breakdown rather frequently. Downtime for the coated plates was 3.48 hours, $46 \%$ of the total time spent on the coated steel plates, while downtime for the coated concrete floor was 4.53 hours, approximately $19 \%$ of the total time spent during the entire operation. Because the downtime was considerably long, the time spent fixing the problems was not taken into account when the production rate is calculated. Even though, the production rate was significantly lower than what was reported in the technology Phase 2 Study Report. The report stated that the production rate ranged from 10 to $120 \mathrm{ft}^{2} / \mathrm{hr}$ depending on level of contamination and coating type.

\subsection{RECOMMENDATIONS FOR TECHNOLOGY ENHANCEMENT}

All the technologies tested exhibited performance and operational advantages as well as disadvantages that would benefit from design improvements. The following recommendations are intended to address specific limitations identified during this project.

With the exception of the Marcrist DTF25 Floor Shaver, one general design improvement that would significantly enhance all aggressive surface removal technologies would be the addition of an integrated removal depth and/or radioactivity sensor. The floor shaver has a depth control knot that can precisely set the working depth from $0.1 \mathrm{~mm}$ to a maximum of $15 \mathrm{~mm}$ per pass. The incorporation of an in-situ sensor technology into these existing decontamination technologies would allow field operators to know precisely when the required removal depth or acceptable contaminant levels have been reached.

\subsubsection{EBE 250}

The vertical shot blaster was mounted on a forklift. Its maneuverability was limited to the forklift movement, and the forklift maneuverability made it difficult to reposition the unit correctly. In addition, the removal gap was too large due to the forklift structure configuration for the unit; therefore, it significantly affected the technology's effectiveness. It is recommended that a mobile crane, scissor lift, or fix beam gantry be utilized in manipulation.

Steel shot occasionally escaped from the system during operation; some even hit evaluators, who stood at a reasonable distance from the equipment. Additionally, a large amount of shot was left on the floor. It is recommended that the debris capture capacity of the system be re-evaluated and improved. 


\subsubsection{EBE 350}

Similar to the EBE $250 \mathrm{VHC}$, the shot occasionally escaped from the EBE 350 during operation and some shot was left on the floor after the decontamination. It is recommended that the debris capture capacity of the system be re-evaluated and improved.

\subsection{3 $\mathrm{ROVCO}_{2}$}

The idea behind this technology was good. The remote controlled operation reduced risk to working personnel, and the use of $\mathrm{CO}_{2}$ minimized secondary waste generation. Nevertheless, the technology encountered operation difficulty throughout the demonstration. Major design modification is recommended. Examples of problems encountered were dry ice overflow, ice jammed in the hopper, control panel not responding, broken seal, and programming trouble.

\subsubsection{Diamond Floor Shaver}

The Marcrist DFT25 Floor Shaver basically completed the required tasks specified. The only part it didn't fulfill was the collection of dust. This would have gotten higher marks if a more efficient dust collector were used. Utilizing a high-performance dust collector is highly recommended in future operation. A remote-controlled operation may also be considered in future system modification.

\subsubsection{Squirrel ${ }^{\circledR}$ III}

The Squirrel ${ }^{\circledast}$ III was designed to tackle small jobs and to get into tight places near corners, wall/floor joints, floor penetrations, steps, and under protruding equipment. It showed a favorable performance during evaluation. If more powerful scabbler bits were used, this technology may become suitable for sites with bigger areas.

\subsubsection{ARMS $^{\mathrm{TM}}$}

The $\mathrm{ARMS}^{\mathrm{TM}}$ required a containment area to capture the media bouncing off the cleaning surfaces and a ventilation system to recycle the air inside the enclosure. A large amount of dust was generated during operation, completely obscuring the view of the operation area. Operators had to wear coveralls and respirators. Neither HEPA filters nor the vapor generator (the latter was demonstrated in FY97) was very effective in dust control. A remotely controlled operation is highly recommended for future development.

Although a vacuum system was used to pick up the media from the floor, the operators often swept the media and manually dumped it into the sifter unit. Media recycle process should be improved. 


\subsubsection{LTC 1072Pn}

Occasionally, the grit media escaped from the blast head, especially when the surface was uneven. Some media and debris were seen on operator's hands and clothes. An increase in dust capture velocity may alleviate the problem.

The articulating arm was optional. During the evaluation, it appeared to be very effective in reducing operator fatigue. The use of the articulating arm is highly recommended in future operation.

\subsubsection{WallWalker}

The removal gap left by this technology was relatively large (up to 45 inches). This could negatively affect the technology's effectiveness, especially when it is used in a relatively small area. Design improvements that would reduce the removal gap left by this technology are highly recommended. 


\subsection{PLANNED ACTIVITIES FOR FY99}

The scope of the technology assessments and data management will be expanded to encompass dismantlement, characterization, and waste management technologies. The evaluation and data management component of this subtask is anticipated to be carried out through FY00 as part of the continuation of this grant.

A Microsoft Windows-based interactive decision analysis model for dismantlement will be planned and designed in FY99. The implementation of the system will take place in FY00. This system will allow site managers to screen prospective dismantlement technology alternatives using filtering parameters. It will allow a user to select quickly the top two or three technologies from a large group of technologies, given user-specified constraints. The continued evaluation of innovative and baseline technologies for decontamination and dismantlement will increase the quantity of technology data available to $D \& D$ professionals.

As part of the on-going Technology Assessment Program at FIU-HCET, the following activities will continue in FY99 and FY00:

- Determine technology needs through review of Site Technology Coordination Group (STCG) web sites.

- Perform detailed review of industries that perform similar activities as those required in D\&D operations to identify additional technologies.

- Define the technology assessment program for characterization and waste management problem sets.

- Define the data management program for characterization, dismantlement, and waste management problem sets.

- Evaluate baseline and innovative technologies under standard test conditions at FIU-HCET and collect performance data in the areas of health and safety, operations and maintenance, and primary and secondary waste generation.

- Continue to locate, verify, and incorporate technology performance data from other sources into the multimedia information system.

- Develop a design for the decision analysis system for dismantlement technologies. 


\subsection{REFERENCES}

1. Dickerson, K.S., August 1995, Contaminated Concrete: Occurrence and Emerging Technologies for DOE Decontamination, Final Report, Health Science Research Division, Oak Ridge National Laboratory, Oak Ridge, TN.

2. Ebadian, M.A., November 1996, Analysis of Potential Concrete Floor Decontamination Technologies, Hemispheric Center for Environmental Technology (HCET), Florida International University, Miami, FL.

3. Ebadian, M.A., and Lagos, L.E., August 1995, Analysis of Potential Surface Blasting Decontamination Technologies for Structural Steel, Final Report, Hemispheric Center for Environmental Technology (HCET), Florida International University, Miami, FL.

4. Ebadian, M.A., and Lagos, L.E., November 1997, Evaluation of Coating Removal and Aggressive Surface Removal Technologies Applied to Concrete Walls, Brick Walls, and Concrete Ceilings, Final Report, Hemispheric Center for Environmental Technology (HCET), Florida International University, Miami, FL. 


\section{APPENDIX A}

\section{TECHNOLOGY DATA DESCRIPTION}




\begin{tabular}{|c|c|c|}
\hline DATA & DESCRIPTION & UNITS \\
\hline$\therefore x^{3}$ & \multicolumn{2}{|l|}{ The following sections can becompleted prior to the demonstration: } \\
\hline 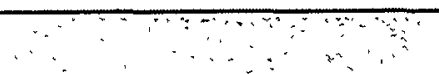 & GENERAL INFORMATION ABOUT TECHNOLOGY & $\therefore$ \\
\hline Technology Name & $\begin{array}{l}\text { The generic name of the technology. Chosen from a list. Examples include: } \\
\text { - Shot blast } \\
\text { - Scabbler, mechanical } \\
\text { - } \mathrm{CO}_{2} \text { blaster }\end{array}$ & NA \\
\hline Technology Model Number & Unique identifier for the technology model. Typically supplied by the manufacturer. & NA \\
\hline $\begin{array}{l}\text { Technology Model } \\
\text { Description }\end{array}$ & $\begin{array}{l}\text { Technical description of the technology including basic principle(s) and operational parameters and } \\
\text { conditions. Discuss all pieces of equipment required by the original manufacturer (e.g., nozzle, liquid } \\
\text { nitrogen tank, cooler) for this technology model. Include dimensions and weight of technology } \\
\text { model. Also, include discussion on how waste is routinely contained for this model and available } \\
\text { options for waste management (e.g., original technology model comes with dustbin, however, vacuum } \\
\text { systems can be attached). }\end{array}$ & $\overline{N A}$ \\
\hline Maturity of Technology & $\begin{array}{l}\text { The maturity of the technology at the time of the demonstration. Choose from: } \\
\text { - Commercially available } \\
\text { - Prototype }\end{array}$ & $\overline{N A}$ \\
\hline $\begin{array}{l}\text { Utility Requirements for } \\
\text { Technology model }\end{array}$ & Energy and material requirements. Includes compressed air and water requirements. & NA \\
\hline $\begin{array}{l}\text { Technology Model Capital } \\
\text { Costs }\end{array}$ & $\begin{array}{l}\text { The vendor's current list price for the entire technology model. Include cost of all pieces (e.g., nozzle, } \\
\text { liquid nitrogen tank, cooler) that are part of the technology model. }\end{array}$ & $\$$ \\
\hline Useful Life Expectancy & The number of years that the technology model can possibly be used for its specified purpose. & Years \\
\hline Applicable Surface Media & $\begin{array}{l}\text { Select all possible substrate compositions to which the technology model can be applied. Chosen from } \\
\text { list. May include more than one option. }\end{array}$ & NA \\
\hline Applicable Geometries & $\begin{array}{l}\text { Select all possible substrate geometries to which the technology model can be applied. Chosen from } \\
\text { list. May include more than one option. }\end{array}$ & NA \\
\hline Removal Capabilities & $\begin{array}{l}\text { The depth of surface media that the technology model is capable of removing. Chosen from a list that } \\
\text { is sorted by Material Type. Select all that apply to this technology model. }\end{array}$ & NA \\
\hline
\end{tabular}




\begin{tabular}{|c|c|c|}
\hline DATA & DESCRIPTION & UNITS \\
\hline Portability Options & $\begin{array}{l}\text { Select one or more ways that are ways for removing the technology model from the transportation } \\
\text { vehicle once it arrives at the facility where the decontamination is to be performed. Options include: } \\
\text { - } 1 \text { person needed - the technology model is small/light and easily carried by one person } \\
\text { - } 2 \text { people needed - the technology model is not as small/light and requires two people to carry it } \\
\text { - Forklift needed - the technology model is large/heavy and requires a forklift to remove it from the } \\
\text { vehicle } \\
\text { - Truck/trailer mounted - the major pieces of the technology model are not removed from the } \\
\text { truck/trailer but instead are operated from this location }\end{array}$ & NA \\
\hline \multicolumn{3}{|c|}{ MANUFACTURERINFORMATION } \\
\hline Name and Address & Information to be collected about company that manufactured the technology model. & NA \\
\hline Phone Number(s) & Include area code. Include pager number or second phone number (if applicable). & NA \\
\hline Fax Number & Manufacturer's fax number including area code. & NA \\
\hline Web-site & Internet web-site location for manufacturer (if applicable). & NA \\
\hline E-Mail & E-mail address for the manufacturer where other D\&D professionals can request information. & NA \\
\hline Services Available & $\begin{array}{l}\text { What services the manufacturer provides. Chosen from one of the following: } \\
\text { - Service provider } \\
\text { - Sells technology model * } \\
\text { - Rents technology model * } \\
\text { ("When these items are chosen, if the manufacturer will train site personnel, include technology model } \\
\text { training time.) }\end{array}$ & NA \\
\hline References & $\begin{array}{l}\text { List of locations where this technology model has been used previously (especially other DOE or } \\
\text { commercial nuclear facilities). }\end{array}$ & NA \\
\hline Publications & $\begin{array}{l}\text { List of brochures or publications that provides additional information about the technology model } \\
\text { and/or the company. }\end{array}$ & NA \\
\hline Photographs/Video & $\begin{array}{l}\text { If photographs or video is received from the manufacturer and sent for inclusion in the database, check } \\
\text { which and the number of each sent to FIU-HCET. }\end{array}$ & $\overline{N A}$ \\
\hline
\end{tabular}




\begin{tabular}{|c|c|c|}
\hline DATA & DESCRIPTION & UNITS \\
\hline$\therefore: \cdots$ & VENDOR INFORMATION & \\
\hline Name and Address & $\begin{array}{l}\text { Information to be collected about the company that was chosen as the vendor for this particular } \\
\text { demonstration. }\end{array}$ & NA \\
\hline Phone Number(s) & Include area code. Include pager number or second phone number (if applicable). & NA \\
\hline Fax Number & Vendor's fax number including area code. & NA \\
\hline Web-site & Internet web-site location for vendor (if applicable). & NA \\
\hline E-Mail & E-mail address for the vendor where other D\&D professionals can request information. & NA \\
\hline Services Available & $\begin{array}{l}\text { What services the vendor provides. Chosen from one of the following: } \\
\text { - Service provider } \\
\text { - Sells technology model * } \\
\text { - Rents technology model * } \\
\text { (* When these items are chosen, if the manufacturer will train site personnel, include technology model } \\
\text { training time.) }\end{array}$ & NA \\
\hline References & $\begin{array}{l}\text { List of locations where this technology model has been used previously (especially other DOE or } \\
\text { commercial nuclear facilities). }\end{array}$ & NA \\
\hline Publications & $\begin{array}{l}\text { List of brochures or publications that provides additional information about the technology and/or the } \\
\text { company. }\end{array}$ & NA \\
\hline$\because \because "$ & GENERAL DEMONSTRATIION INFORMATION & \\
\hline Demonstration Site & $\begin{array}{l}\text { Location of demonstration including name of DOE facility (if applicable) and city/state. Example } \\
\text { includes: } \\
\text { - CP-5, Argonne National Laboratory, Chicago, IL } \\
\text { - FIU-HCET, Miami, FL }\end{array}$ & NA \\
\hline $\begin{array}{l}\text { Demonstration Start and } \\
\text { End Dates }\end{array}$ & Dates from start to finish for this particular demonstration. Example: June 2-7, 1998 & NA \\
\hline
\end{tabular}




\begin{tabular}{|c|c|c|}
\hline DATA & DESCRIPTION & UNITS \\
\hline $\begin{array}{l}\text { Testing Organization, } \\
\text { Contact Name, Phone } \\
\text { Number, and E-Mail }\end{array}$ & $\begin{array}{l}\text { The name of the organization responsible for this demonstration and the information on a contact } \\
\text { person who can be reached to gather additional information about all of the demonstrations performed } \\
\text { by that organization. An example of the correct format: } \\
\text { - XYZ Program, Jane Doe, (111) 555-5183, j.doe@example.com } \\
\text { (Note: the contact name and information will not be accessible on the Internet - it is for FIU-HCET } \\
\text { information only to assist in collecting the most accurate data for the database) }\end{array}$ & NA \\
\hline Test Engineer Name & $\begin{array}{l}\text { The name of the person from the test organization in charge of setting up and evaluating this particular } \\
\text { demonstration. } \\
\text { (Note: this information will not be accessible on the Internet - it is for FIU-HCET information only to } \\
\text { assist in collecting the most accurate data for the database) }\end{array}$ & $\mathrm{NA}$ \\
\hline $\begin{array}{l}\text { Vendor Principal } \\
\text { Investigator Name }\end{array}$ & $\begin{array}{l}\text { The name of the vendor personnel that is supervising the demonstration from the demonstration site. } \\
\text { (Note: this information will not be accessible on the Internet - it is for FIU-HCET information only to } \\
\text { assist in collecting the most accurate data for the database) }\end{array}$ & $\mathrm{NA}$ \\
\hline $\begin{array}{l}\text { Size of Area Assigned } \\
\text { (include units) }\end{array}$ & $\begin{array}{l}\text { Describe the size of the surface area to be attempted by the technology model during the } \\
\text { demonstration. Examples include: } \\
\text { - } 800 \mathrm{ft}^{2} \\
\text { - Number that can be completed in } 4 \text { hours. }\end{array}$ & $\begin{array}{c}\text { User } \\
\text { defined }\end{array}$ \\
\hline $\begin{array}{l}\text { Demonstrated Surface } \\
\text { Media }\end{array}$ & $\begin{array}{l}\text { The substrate composition on which this particular demonstration was performed. Chosen one item } \\
\text { from list. Examples include: } \\
\text { - Concrete - poured } \\
\text { - Stainless steel } \\
\text { - Brick }\end{array}$ & $\mathrm{NA}$ \\
\hline
\end{tabular}




\begin{tabular}{|c|c|c|}
\hline DATA & DESCRIPTION & UNITS \\
\hline Surface Media Description & $\begin{array}{l}\text { A written description describing the surface media demonstrated. May include the following } \\
\text { information: } \\
\text { - type and thickness of coating being removed } \\
\text { - diameter of pipe being decontaminated and whether they were in-situ or in small pieces } \\
\text { - } \text { age of substrate being decontaminated } \\
\text { - hardness of concrete } \\
\text { - } \text { outside or inside demonstration location } \\
\text { - type of metal }\end{array}$ & NA \\
\hline Demonstrated Geometry & $\begin{array}{l}\text { The substrate geometry that this particular demonstration was performed. Chosen one from list. } \\
\text { Examples include: } \\
\text { - Equipment } \\
\text { - Floor } \\
\text { - Wall }\end{array}$ & NA \\
\hline 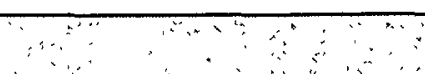 & VENDOR SUPPLLIED INFORMATION & \\
\hline $\begin{array}{l}\text { Removal Media Type and } \\
\text { Cost per Unit }\end{array}$ & $\begin{array}{l}\text { Type of media used by the technology model demonstrated and its cost per User Defined unit. } \\
\text { - } \text { steel shot } \# 2-\$ 50 / \mathrm{lb} \\
\text { - } \text { sponge }-\$ 16 / \mathrm{lb} \\
\text { - } \quad \text { water, } 10,000 \mathrm{psig}-\$ 5 / \mathrm{gal} \\
\text { - } \quad \text { scabbler bit - } \$ 200 \text { each }\end{array}$ & $\begin{array}{l}\text { \$/User } \\
. \times \text { Defined }\end{array}$ \\
\hline $\begin{array}{l}\text { Required Personnel for } \\
\text { Operation }\end{array}$ & $\begin{array}{l}\text { Manpower requirements for operation of this technology. Distinguish between number of equipment } \\
\text { operators and number of technicians required. }\end{array}$ & NA \\
\hline $\begin{array}{l}\text { Technology Model } \\
\text { Availability }\end{array}$ & Average expected delay between order placement and vendor delivery. Chosen from a list. & $\overline{\mathrm{NA}}$ \\
\hline Scale-up Requirements & $\begin{array}{l}\text { For vendors who are service providers only. Provide a description of what equipment/personnel would } \\
\text { be changed or added by the vendor if the size of the decontamination job was } 10,000 \mathrm{ft}^{2} \text { or greater. }\end{array}$ & $\therefore \quad N A$ \\
\hline
\end{tabular}




\begin{tabular}{|c|c|c|}
\hline DATA & DESCRIPTION & UNITS \\
\hline Maintenance Requirements & $\begin{array}{l}\text { Listing of the maintenance requirements for the technology model. Include time frames to perform } \\
\text { maintenance. Examples include: } \\
\text { - change filter every } 6 \text { months } \\
\text { - add oil motor at end of every day }\end{array}$ & NA \\
\hline $\begin{array}{l}\text { Total Maintenance } \\
\text { Cost per } \mathrm{ft}^{2}\end{array}$ & Include total cost of regular maintenance per $\mathrm{ft}^{2}$ of surface area. & $\$ / \mathrm{tt}^{2}$ \\
\hline $\begin{array}{l}\text { Technology Support } \\
\text { Equipment and Cost for } \\
\text { Each Unit }\end{array}$ & $\begin{array}{l}\text { List any required support equipment (not utilities) that are included in the demonstration. Include } \\
\text { description of each and associated capital costs. Examples include: } \\
\text { - vacuum system, } \$ 5000 \\
\text { - floor magnet, } \$ 150 \\
\text { - ARMS Media Remake Unit, } \$ 15,000\end{array}$ & $\$$ \\
\hline $\begin{array}{l}\text { Consumables and Cost for } \\
\text { Each Unit }\end{array}$ & $\begin{array}{l}\text { List expendable items and associated costs for each item, used with the technology that are typically } \\
\text { discarded at the end of a job. Examples include: } \\
\text { - vacuum hoses, } \$ 200 \\
\text { - HEPA filters, } \$ 500\end{array}$ & $\$$ \\
\hline \multicolumn{3}{|c|}{ The following sections are to be completed during or immediately after demonstration } \\
\hline \multicolumn{3}{|c|}{ ODENONSTRATIONSTATISTICS } \\
\hline Mobilization Time & $\begin{array}{l}\text { A measured time for how long it takes to mobilize the technology model prior to performing } \\
\text { decontamination. This time measures from the time the vendor arrives at the demonstration site to } \\
\text { when the technology model is ready to operate. }\end{array}$ & $h$ \\
\hline Portability Option Chosen & $\begin{array}{l}\text { List of equipment/ personnel used at this particular demonstration to remove the technology model } \\
\text { from the vendor vehicle during mobilization/demobilization. Choose from a list. }\end{array}$ & $\overline{N A}$ \\
\hline $\begin{array}{l}\text { Required PPE for } \\
\text { Demonstration }\end{array}$ & $\begin{array}{l}\text { Select all of the PPE that was required to operate the technology model during the demonstration. If } \\
\text { different levels of PPE were worn by the equipment operator and technicians, describe the most } \\
\text { restrictive. Chosen from a list. }\end{array}$ & NA \\
\hline $\begin{array}{l}\text { Technology Model } \\
\text { Maneuverability }\end{array}$ & $\begin{array}{l}\text { Ease of moving technology model across the substrate, turning corners, rotating, maneuvering around } \\
\text { obstacles. Include examples whenever possible. }\end{array}$ & $\overline{N A}$ \\
\hline
\end{tabular}




\begin{tabular}{|c|c|c|}
\hline DATA & DESCRIPTION & UNITS \\
\hline $\begin{array}{l}\text { Area of Surface } \\
\text { Decontaminated }\end{array}$ & Measured area of surface media removed during the demonstration. & $\mathrm{ft}^{2}$ \\
\hline Production Rate & $\begin{array}{l}\text { The total area of surface media decontaminated divided by the total number of hours of operation } \\
\text { required to complete the task. Includes from the time the vendor begins the decontamination of the } \\
\text { surface media until the vendor states that the decontamination of the surface media is completed. } \\
\text { Does include drum changes, surface media cleanup (vacuuming), and routine maintenance. Does not } \\
\text { include time spent in set-up, major equipment breakdown, technology model decontamination, } \\
\text { demobilization, donning or doffing PPE, or personnel breaks/meals. }\end{array}$ & $\mathrm{ft}^{2} / \mathrm{h}$ \\
\hline $\begin{array}{l}\text { Depth of Surface Removed } \\
\text { and Method for Determining } \\
\text { Depth }\end{array}$ & $\begin{array}{l}\text { The depth of surface media that was measured to have been removed during this particular } \\
\text { demonstration. Include the method used to determine this value (e.g., ruler, visual inspection, and } \\
\text { professional survey). }\end{array}$ & inches \\
\hline Removal Gap & $\begin{array}{l}\text { The measured area between the edge of the surface media and an adjacent surface that the } \\
\text { technology was not able to reach. Examples include the area where the floor meets the wall or two } \\
\text { walls meet. }\end{array}$ & $\therefore$ inches \\
\hline Removal Media Usage Rate & $\begin{array}{l}\text { A measure of the amount of removal media that was used during this particular demonstration with } \\
\text { respect to the area of surface removed. Define the unit to be entered (e.g., scabbling piston }-0.025 \\
\left.\text { each/ft } \mathrm{t}^{2}, 10,000 \text { psig water }-1 \text { gallon/ } / \mathrm{ft}^{2}\right) \text {. }\end{array}$ & Unit/ft $^{2}$ \\
\hline $\begin{array}{l}\text { Technology Model } \\
\text { Decontamination Method }\end{array}$ & $\begin{array}{l}\text { The method used to clean and decontaminate the technology model after the demonstration is } \\
\text { completed. Examples include: } \\
\text { - wiped with damp rags } \\
\text { - could not be decontaminated } \\
\text { - cleaned using soft media blasting equipment } \\
\text { - stainless steel construction makes for easy decontamination by wiping with damp rags. }\end{array}$ & NA \\
\hline Demobilization Time & $\begin{array}{l}\text { A measured time for how long it takes to demobilize the technology model after surface } \\
\text { decontamination. This time measures from the time the technology model is ready to be } \\
\text { decontaminated to when the vendor leaves the demonstration site. }\end{array}$ & $\mathrm{h}$ \\
\hline Ending Surface Condition & $\begin{array}{l}\text { Description of surface condition once this particular demonstration has been completed. Chosen from } \\
\text { a list. }\end{array}$ & NA \\
\hline
\end{tabular}




\begin{tabular}{|c|c|c|}
\hline DATA & DESCRIPTION & UNITS \\
\hline Waste Volume & $\begin{array}{l}\text { The measured volume of primary/secondary waste generated during this particular demonstration with } \\
\text { respect to the area of surface removed. This includes only the removed surface media and the spent } \\
\text { removal media. Other secondary waste (e.g., vacuum hoses and filters) is entered under } \\
\text { Consumables. }\end{array}$ & $\mathrm{ft}^{3} / \mathrm{ft}^{2}$ \\
\hline Waste Characteristics & $\begin{array}{l}\text { The description of primary/secondary waste generated during this particular demonstration with } \\
\text { respect to the area of surface removed. This includes only the removed surface media and the spent } \\
\text { removal media. Other secondary waste (e.g., vacuum hoses and filters) is entered under } \\
\text { Consumables. }\end{array}$ & NA \\
\hline \multicolumn{3}{|c|}{ 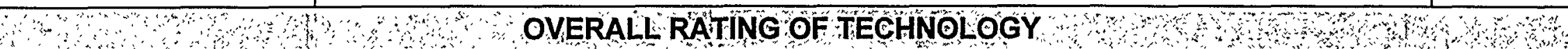 } \\
\hline Effectiveness & $\begin{array}{l}\text { Qualitative evaluation of how the technology model demonstrated did achieve the desired effect. Scale } \\
\text { of } 1-4 \text {, with } 4 \text { being the highest. Include reason rating was given including decontamination factors and } \\
\text { whether final outcome of demonstration met site needs, and if not, what needs were not met. }\end{array}$ & NA \\
\hline Benefits & $\begin{array}{l}\text { Technical and economic advantage(s) of the technology over competing technologies (e.g., lower cost, } \\
\text { greater degree of cleanup, more stable waste form, increased safety). }\end{array}$ & NA \\
\hline Limitations & $\begin{array}{l}\text { Disadvantages or shortfalls the technologies has (e.g., conditions under which the technology shall not } \\
\text { be used at this time). Include any outstanding design issues and/or problems that may have been } \\
\text { encountered during the demonstration or post-demonstration. }\end{array}$ & NA \\
\hline Data Sensitivities & $\begin{array}{l}\text { Description of items that could affect the quality of the data collected. Examples may include: } \\
\text { - Vendor statement that the equipment/personnel used at the demonstration is not what would be } \\
\text { used in routine decontamination jobs } \\
\text { - Vendor statement that demonstration conditions (media, heat, condition of surface media) were } \\
\text { unlike what would be seen in normal jobs and adversely effected their performance as seen in the } \\
\text { statistics } \\
\text { - Information about data that was misplaced or unsure of accuracy. }\end{array}$ & NA \\
\hline Photographs and Video & $\begin{array}{l}\text { Please include at least one photograph and video clip of the technology while performing } \\
\text { decontamination activities. These will be placed on the web site for other D\&D professionals to view. }\end{array}$ & $\overline{N A}$ \\
\hline
\end{tabular}




\begin{tabular}{|c|c|c|}
\hline DATA & DESCRIPTION & UNITS \\
\hline \multicolumn{3}{|c|}{ 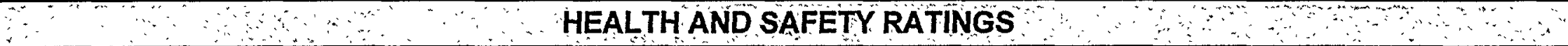 } \\
\hline Electrical & $\begin{array}{l}\text { A risk rating (from } 1 \text { to } 4 \text { ) and a description of the hazards associated with this particular technology } \\
\text { and/or demonstration. If not applicable to this technology model, choose NA. }\end{array}$ & $\mathrm{NA}$ \\
\hline Fire/Explosion & $\begin{array}{l}\text { A risk rating (from } 1 \text { to } 4 \text { ) and a description of the hazards associated with this particular technology } \\
\text { and/or demonstration. If not applicable to this technology model, choose NA. }\end{array}$ & $\overline{N A}$ \\
\hline Confined Space Entry & $\begin{array}{l}\text { A risk rating (from } 1 \text { to } 4 \text { ) and a description of the hazards associated with this particular technology } \\
\text { and/or demonstration. If not applicable to this technology model, choose NA. }\end{array}$ & $\mathrm{NA}$ \\
\hline Mechanical Hazards & $\begin{array}{l}\text { A risk rating (from } 1 \text { to } 4 \text { ) and a description of the hazards associated with this particular technology } \\
\text { and/or demonstration. If not applicable to this technology model, choose NA. }\end{array}$ & NA \\
\hline Pressure Hazards & $\begin{array}{l}\text { A risk rating (from } 1 \text { to } 4 \text { ) and a description of the hazards associated with this particular technology } \\
\text { and/or demonstration. If not applicable to this technology model, choose NA. }\end{array}$ & NA \\
\hline Tripping and Falling & $\begin{array}{l}\text { A risk rating (from } 1 \text { to } 4 \text { ) and a description of the hazards associated with this particular technology } \\
\text { and/or demonstration. If not applicable to this technology model, choose NA. }\end{array}$ & NA \\
\hline Moving Vehicles & $\begin{array}{l}\text { A risk rating (from } 1 \text { to } 4 \text { ) and a description of the hazards associated with this particular technology } \\
\text { and/or demonstration. If not applicable to this technology model, choose NA. }\end{array}$ & $\overline{N A}$ \\
\hline Protruding Objects & $\begin{array}{l}\text { A risk rating (from } 1 \text { to } 4 \text { ) and a description of the hazards associated with this particular technology } \\
\text { and/or demonstration. If not applicable to this technology model, choose NA. }\end{array}$ & $\overline{N A}$ \\
\hline Overhead Lifts & $\begin{array}{l}\text { A risk rating (from } 1 \text { to } 4 \text { ) and a description of the hazards associated with this particular technology } \\
\text { and/or demonstration. If not applicable to this technology model, choose NA. }\end{array}$ & NA \\
\hline Inhalation & $\begin{array}{l}\text { A risk rating (from } 1 \text { to } 4 \text { ) and a description of the hazards associated with this particular technology } \\
\text { and/or demonstration. Include any measured airborne radioactive contamination levels or measured } \\
\text { respirable dust levels. If not applicable to this technology model, choose NA. }\end{array}$ & $\mathrm{NA}$ \\
\hline Skin Absorption & $\begin{array}{l}\text { A risk rating (from } 1 \text { to } 4 \text { ) and a description of the hazards associated with this particular technology } \\
\text { and/or demonstration. If not applicable to this technology model, choose NA. }\end{array}$ & NA \\
\hline Heat Stress & $\begin{array}{l}\text { A risk rating (from } 1 \text { to } 4 \text { ) and a description of the hazards associated with this particular technology } \\
\text { and/or demonstration. If not applicable to this technology model, choose NA. }\end{array}$ & NA \\
\hline
\end{tabular}




\begin{tabular}{|c|c|c|}
\hline DATA & DESCRIPTION & UNITS \\
\hline Noise & $\begin{array}{l}\text { A risk rating (from } 1 \text { to } 4 \text { ) and a description of the hazards associated with this particular technology } \\
\text { and/or demonstration. Include any measured noise levels. If not applicable to this technology model, } \\
\text { choose NA. }\end{array}$ & NA \\
\hline Cold Stress & $\begin{array}{l}\text { A risk rating (from } 1 \text { to } 4 \text { ) and a description of the hazards associated with this particular technology } \\
\text { and/or demonstration. If not applicable to this technology model, choose NA. }\end{array}$ & $\mathrm{NA}$ \\
\hline Ergonomic Hazards & $\begin{array}{l}\text { A risk rating (from } 1 \text { to } 4 \text { ) and a description of the hazards associated with this particular technology } \\
\text { and/or demonstration. If not applicable to this technology model, choose NA. }\end{array}$ & NA \\
\hline Other & Allowing the test engineer to add additional risks not listed above. & NA \\
\hline
\end{tabular}




\section{APPENDIX B}

\section{TECHNOLOGY SUMMARY}




\section{B.1 TECHNOLOGY OVERVIEW}

\section{Technology Class: Soft Media Blasting}

\section{Name: Advanced Recyclable Media System (ARMS ${ }^{\top M}$ )}

Technology Description: The ARMS ${ }^{\text {TN }}$ equipment is comprised of a feed unit and a sifter unit. The feed unit is a portable pneumatically powered device that propels the sponge media against the contaminated surface. Sponge media is manually loaded into a hopper mounted on top of the feed unit, and is fed to an auger device that mixes the cleaning media with compressed air. The media is then transported through the standard abrasive blasting hose and the blasting nozzle to the surface being removed. The sifter unit mechanically removes large debris and powdery residues from the sponge media after use. The sifter vibrates causing the media to fall downward through a series of separation screens to remove the debris from the recyclable media. The media is aluminum oxide fiber, Type B. This media is highly absorptive, and was capable of capturing, absorbing and removing a variety of surface contaminants.

\begin{tabular}{|c|c|c|c|c|c|c|c|c|c|}
\hline $\begin{array}{c}\text { Equipment } \\
\text { Dimension/ } \\
\text { Weight }\end{array}$ & $\begin{array}{l}\text { Estimated } \\
\text { Capital } \\
\text { Cost }\end{array}$ & Benefits & Limitations & $\begin{array}{l}\text { Production } \\
\text { Rate }\end{array}$ & $\begin{array}{c}\text { Labor } \\
\text { Classification }\end{array}$ & $\begin{array}{l}\text { Environmental } \\
\text { Conditions }\end{array}$ & $\begin{array}{l}\text { End Point } \\
\text { Achieved }\end{array}$ & $\begin{array}{l}\text { Characteristics } \\
\text { of Waste }\end{array}$ & $\begin{array}{c}\text { Support } \\
\text { Equipment }\end{array}$ \\
\hline $\begin{array}{l}\text { Dimension } \\
(\mathrm{L} \times \mathrm{W} \times \mathrm{H}) \\
\text { The Feed } \\
\text { Unit } 32 " \times \\
32 " \times 60 " \\
\text { The } \\
\text { Screening or } \\
\text { Sifter Unit } \\
72 " \times 32 " \times \\
72 " \\
\text { Weight } \\
\text { The Feed } \\
\text { Unit } 450 \mathrm{lb} \\
\text { The } \\
\text { Screening or } \\
\text { Sifter Unit } \\
400 \mathrm{lb}\end{array}$ & $\begin{array}{l}\text { ARMS }^{T M} \\
\text { Feed unit - } \\
\$ 10,800 \\
\\
\text { ARMS }^{T M} \\
\text { Sifter unit - } \\
\$ 8,000\end{array}$ & $\begin{array}{l}\text { Media is } \\
\text { recyclable, } \\
\text { thus } \\
\text { reducing } \\
\text { waste } \\
\text { generation. } \\
\text { Simple blast } \\
\text { hose design } \\
\text { requires } \\
\text { little training } \\
\text { and easy } \\
\text { operation. } \\
\text { Able to } \\
\text { operate with } \\
\text { little } \\
\text { maintenance. }\end{array}$ & $\begin{array}{l}\text { The blasting } \\
\text { unit needs to } \\
\text { be operated in } \\
\text { a contained } \\
\text { area. } \\
\text { Media has to } \\
\text { be constantly } \\
\text { recycled } \\
\text { manually, } \\
\text { which } \\
\text { increases } \\
\text { operator } \\
\text { fatigue. } \\
\text { Airborne dust } \\
\text { requires } \\
\text { operators to } \\
\text { wear full-face } \\
\text { respirators. }\end{array}$ & $\begin{array}{l}\text { Coated brick } \\
\text { wall: } 16.43 \\
\mathrm{ft}^{2} / \mathrm{hr} \\
\\
\text { Coated } \\
\text { concrete } \\
\text { floor: } 26 \\
\mathrm{f} \mathrm{f}^{2} / \mathrm{hr} \\
\\
\text { Note: some } \\
\text { primer } \\
\text { coating was } \\
\text { remained on } \\
\text { the floor } \\
\text { after } \\
\text { decontami- } \\
\text { nation. }\end{array}$ & $\begin{array}{l}\text { Equipment } \\
\text { operators: } 1 \\
\text { Technicians: } 2\end{array}$ & $\begin{array}{l}\text { Average exposure } \\
\text { Dust level inside } \\
\text { blasting chamber: } \\
459 \mathrm{mg} / \mathrm{m}^{3} \\
\text { Noise level: } \\
108.8 \mathrm{dBA}\end{array}$ & $\begin{array}{l}\text { Brick wall } \\
\text { removal } \\
\text { depth: } \\
\text { coating } \\
\text { removal } \\
\text { End surface } \\
\text { condition: } \\
\text { Rough, } \\
\text { bare, } \\
\text { uneven } \\
\text { surface } \\
\text { Coated } \\
\text { concrete } \\
\text { floor: } \\
\text { Smooth, } \\
\text { even } \\
\text { surface } \\
\text { with some } \\
\text { primer } \\
\text { coating } \\
\text { remaining } \\
\text { on the floor }\end{array}$ & $\begin{array}{l}\text { Fine brick or } \\
\text { concrete powder } \\
\text { with spent media }\end{array}$ & $\begin{array}{l}\text { Air } \\
\text { compressor } \\
-250 \mathrm{cfm}, \\
90 \mathrm{psi} \\
-\$ 5.62 / \mathrm{hr} \\
\\
\text { Generator - } \\
15 \mathrm{~kW} \\
\$ 4.20 / \mathrm{hr}\end{array}$ \\
\hline
\end{tabular}




\section{Technology Class: Shot Blasting}

\section{Name: EBE 250 VHC}

Technology Description: The EBE 250 VHC is a remotely operated shot blasting system, which was designed to operate on vertical surfaces. It consists of two main units. One is a self-propelled blast head, which blasts the contaminated surface with steel shots, and the other is a remote vacuum unit (EBE 250DA), which collects the dust, debris and the spent media. Debris is separated from the abrasive within the machine on a continuous basis: separated abrasive is reused, debris is transported to the dust collector.

\begin{tabular}{|c|c|c|c|c|c|c|c|c|c|}
\hline $\begin{array}{c}\text { Equipment } \\
\text { Dimension/ } \\
\text { Weight }\end{array}$ & $\begin{array}{c}\text { Estimated } \\
\text { Capital } \\
\text { Cost }\end{array}$ & Benefits & Limitations & $\begin{array}{l}\text { Production } \\
\text { Rate }\end{array}$ & $\begin{array}{c}\text { Labor } \\
\text { Classification }\end{array}$ & $\begin{array}{l}\text { Environmental } \\
\text { Conditions }\end{array}$ & $\begin{array}{l}\text { End Point } \\
\text { Achieved }\end{array}$ & $\begin{array}{l}\text { Characteristics } \\
\text { of Waste }\end{array}$ & $\begin{array}{c}\text { Support } \\
\text { Equipment }\end{array}$ \\
\hline $\begin{array}{l}\text { Blast Head: } \\
27.5 " \mathrm{~W} \times \\
27.5 " \mathrm{~L} \times \\
51 " \mathrm{H}(550 \\
\text { lb.) } \\
\text { Dust } \\
\text { Collector: } \\
27.5 " \mathrm{~W} \times \\
69 " \mathrm{~L} \times 64 " \\
\mathrm{H}(990 \mathrm{lb} .)\end{array}$ & $\$ 89,000$ & $\begin{array}{l}\text { The shot is } \\
\text { inexpensive. } \\
\text { Process is } \\
\text { not labor } \\
\text { intensive. } \\
\text { Easy to } \\
\text { operate. } \\
\text { Remotely } \\
\text { operated. }\end{array}$ & $\begin{array}{l}\text { Leaves large } \\
\text { gaps. Inefficient } \\
\text { for small areas. } \\
\text { Cannot work on } \\
\text { wet surfaces. } \\
\text { Forklift } \\
\text { maneuverability } \\
\text { makes it } \\
\text { difficult to } \\
\text { correctly } \\
\text { reposition the } \\
\text { unit. } \\
\text { Some shots } \\
\text { escaped during } \\
\text { operation. }\end{array}$ & $\begin{array}{l}\text { Uncoated } \\
\text { concrete wall: } \\
13.6 \mathrm{ft}^{2} / \mathrm{hr} \\
\text { Coated } \\
\text { concrete wall: } \\
12.59 \mathrm{ft}^{2} / \mathrm{hr} \\
\text { Coated brick } \\
\text { wall: } \\
26.42 \mathrm{ft}^{2} / \mathrm{hr}\end{array}$ & 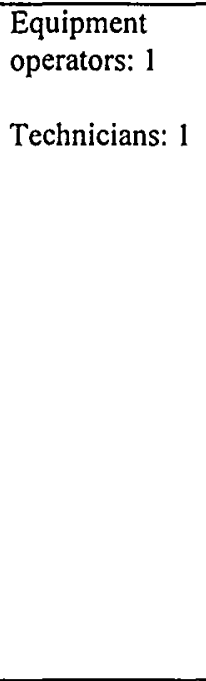 & $\begin{array}{l}\text { Average } \\
\text { exposure } \\
\text { Dust level: } 21.6 \\
\mathrm{mg} / \mathrm{m}^{3}\end{array}$ & $\begin{array}{l}\text { Rough, bare, } \\
\text { and uneven } \\
\text { surface } \\
0.25^{\prime \prime} \\
\text { removal } \\
\text { depth for } \\
\text { brick wall } \\
\text { and concrete } \\
\text { walls. }\end{array}$ & $\begin{array}{l}\text { Fine brick or } \\
\text { concrete powder } \\
\text { and spent media. }\end{array}$ & $\begin{array}{l}\text { Floor } \\
\text { magnet: } \\
\$ 500.00\end{array}$ \\
\hline
\end{tabular}


Technology Class: Shot Blasting

\section{Name: EBE 350}

Technology Description: The EBE 350 Floor Shot Blaster consists of a self-propelled blaster connected to a vacuum unit for dust collection. The blast head releases abrasive at a high velocity to contaminated surfaces being cleaned. The abrasive and the material are mechanically reclaimed within the machine. The abrasive is then reused, and the debris is drawn into vacuum system for collection and disposal. The dust collector is a separate unit that can be placed at up to $600 \mathrm{ft}$ away from the blast head. The dust collector includes a series of pulse jet operated pre-filters and a HEPA filter. The dust is collected in the dust bin and later transferred to a 55-gallon drum for disposal. The blast head unit is capable of reaching up to $1 / 2$ " removal depth, depending on the surface media. The blast path is $13 "$.

\begin{tabular}{|c|c|c|c|c|c|c|c|c|c|}
\hline $\begin{array}{c}\text { Equipment } \\
\text { Dimension/ } \\
\text { Weight }\end{array}$ & $\begin{array}{c}\text { Estimated } \\
\text { Capital } \\
\text { Cost }\end{array}$ & Benefits & Limitations & $\begin{array}{c}\text { Production } \\
\text { Rate }\end{array}$ & $\begin{array}{c}\text { Labor } \\
\text { Classification }\end{array}$ & $\begin{array}{c}\text { Environmental } \\
\text { Conditions }\end{array}$ & $\begin{array}{l}\text { End Point } \\
\text { Achieved }\end{array}$ & $\begin{array}{c}\text { Characteristics } \\
\text { of Waste }\end{array}$ & $\begin{array}{c}\text { Support } \\
\text { Equipment }\end{array}$ \\
\hline $\begin{array}{l}\text { Blast Head: } \\
26 " \mathrm{~W} \times 54 " \\
\mathrm{~L} \times 44 " \mathrm{H} \\
(772 \mathrm{lb} \text {.) } \\
\text { Dust } \\
\text { Collector: } \\
28 \text { " W } \times 69 " \\
\mathrm{~L} \times 64 " \mathrm{H} \\
(990 \mathrm{lb} .)\end{array}$ & $\begin{array}{l}\text { EBE 350 } \\
\text { Floor Shot } \\
\text { Blaster: } \\
\$ 79,000 \\
\\
\text { Dust } \\
\text { Collector: } \\
\$ 23,000\end{array}$ & $\begin{array}{l}\text { Requires minimal } \\
\text { setup time to } \\
\text { begin blasting. } \\
\text { Self-propelled } \\
\text { unit, reduce labor } \\
\text { Maintains a dust } \\
\text { free environment. } \\
\text { Novice operators } \\
\text { can become } \\
\text { productive soon } \\
\text { after basic } \\
\text { training. } \\
\text { Dust collector can } \\
\text { stay stationary at } \\
\text { up to } 600 \mathrm{ft} \text { away } \\
\text { The abrasive is } \\
\text { reused to reduce } \\
\text { cost and waste } \\
\text { generation. }\end{array}$ & $\begin{array}{l}\text { Not } \\
\text { Operational } \\
\text { on wet } \\
\text { surfaces. } \\
\text { Shots escaped } \\
\text { and hit the } \\
\text { evaluators. } \\
\text { Some shots } \\
\text { remained on } \\
\text { the floor } \\
\text { after the } \\
\text { demonstration }\end{array}$ & $\begin{array}{l}\text { Coated } \\
\text { concrete } \\
\text { floor: } 65.17 \\
\mathrm{ft}^{2} / \mathrm{hr} \\
\\
\text { Uncoated } \\
\text { concrete } \\
\text { floor: } 61.58 \\
\mathrm{ft}^{2} / \mathrm{hr}\end{array}$ & $\begin{array}{l}\text { Equipment } \\
\text { operators: } 1\end{array}$ & $\begin{array}{l}\text { Average } \\
\text { exposure } \\
\text { Dust level: } \\
\text { Not Available } \\
\text { Average } \\
\text { exposure } \\
\text { noise level: } \\
\text { Not Available }\end{array}$ & $\begin{array}{l}\text { Rough, } \\
\text { bare, and } \\
\text { uneven } \\
\text { surface } \\
\text { Removal } \\
\text { depth } \\
\text { Coated } \\
\text { concrete } \\
\text { floor: } 0.336 \\
\pm 0.0597 \\
\text { in. } \\
\text { Uncoated } \\
\text { concrete } \\
\text { floor: } 0.330 \\
\pm 0.0372 \\
\text { in. }\end{array}$ & $\begin{array}{l}\text { Coated concrete } \\
\text { floor: Fine } \\
\text { powder } \\
\text { containing } \\
\text { removed concrete } \\
\text { and spent steel } \\
\text { shot. } \\
\text { Uncoated } \\
\text { concrete floor: } \\
\text { Fine powder } \\
\text { containing } \\
\text { removed concrete } \\
\text { and spent steel } \\
\text { shot. }\end{array}$ & $\begin{array}{l}\text { Floor } \\
\text { Magnet: } \\
\$ 500\end{array}$ \\
\hline
\end{tabular}


Technology Class: Grit Blasting

Name: LTC 1072Pn

Technology Description: The technology model LTC 1072Pn is a grit blasting machine with a dual nozzle capability. This machine works on the principle of dry abrasive blasting and a mechanism of simultaneous recovery of the abrasive and the waste generated. This technology is configured with a compressor linked to cooler dryer unit, which in turn is linked to the machine. The air requirement for the LTC 1072 technology is $1300 \mathrm{cfm}$ at $150 \mathrm{psi}$. The LTC 1072Pn consists of a dual pressure chamber vessel, two vacuum generators (each having a built in venturi), two primary filters, an optional HEPA filter and a scaled half drum for emission free waste disposal. The newest addition to the LTC 1072Pn is the Concrete Filter Cleaning Valve (CFCV). This valve increases the continuous blasting time between two filter cleaning pauses for the 1072. Thus, with the CFCV, the continuos blasting time on concrete is increased to 30 minutes or longer (instead of the 15 minutes blasting time if the CFCV was not used). Additionally this technology can be linked to optional electronic controls that would allow automatic shut down at individual blast heads during the blasting operation, if the blast head were accidentally displaced away from the surface or if the differential pressure across the filters exceeded the programmed maxima.

\begin{tabular}{|c|c|c|c|c|c|c|c|c|c|}
\hline $\begin{array}{c}\text { Equipment } \\
\text { Dimension/ } \\
\text { Weight }\end{array}$ & $\begin{array}{c}\text { Estimated } \\
\text { Capital } \\
\text { Cost }\end{array}$ & Benefits & Limitations & $\begin{array}{c}\text { Production } \\
\text { Rate }\end{array}$ & $\begin{array}{c}\text { Labor } \\
\text { Classification }\end{array}$ & $\begin{array}{c}\text { Environmental } \\
\text { Conditions }\end{array}$ & $\begin{array}{l}\text { End Point } \\
\text { Achieved }\end{array}$ & $\begin{array}{c}\text { Characteristics } \\
\text { of Waste }\end{array}$ & $\begin{array}{c}\text { Support } \\
\text { Equipment }\end{array}$ \\
\hline $\begin{array}{l}72 " \mathrm{~L} \times \\
28.5 " \mathrm{~W} \times \\
79.5 " \mathrm{H} \\
1900 \mathrm{lb} . \\
\text { (empty) } \\
2500 \mathrm{lb} \text {. } \\
\text { (filled with } \\
\text { abrasive) }\end{array}$ & $\$ 44,763.00$ & $\begin{array}{l}\text { Removal gap } \\
\text { is very small } \\
\text { and in most } \\
\text { cases non- } \\
\text { existent. } \\
\text { Low levels of } \\
\text { airborne } \\
\text { particles, } \\
\text { which creates } \\
\text { a safer } \\
\text { working } \\
\text { environment. } \\
\text { Auto recycle } \\
\text { of media. } \\
\text { Two or even } \\
\text { three blast } \\
\text { heads can be } \\
\text { attached to } \\
\text { one base } \\
\text { blasting } \\
\text { equipment, } \\
\text { thus } \\
\text { increasing } \\
\text { productivity. }\end{array}$ & $\begin{array}{l}\text { Cannot blast on wet or } \\
\text { moist surfaces. } \\
\text { The system is not so } \\
\text { effective on brick } \\
\text { surfaces as it is on } \\
\text { concrete surfaces. } \\
\text { Because the mortar } \\
\text { joint is softer than the } \\
\text { brick, some of the } \\
\text { abrasive tends to come } \\
\text { out of the sides } \\
\text { between the blast head } \\
\text { and the mortar joints, } \\
\text { thus restricting the } \\
\text { equipment from } \\
\text { achieving a better } \\
\text { depth of removal. } \\
\text { Relatively labor } \\
\text { intensive when the } \\
\text { unit is hand held. The } \\
\text { use of articulating arm } \\
\text { helps to alleviate the } \\
\text { problem. }\end{array}$ & $\begin{array}{l}\text { Coated } \\
\text { brick wall: } \\
17.65 \mathrm{ft}^{2} / \mathrm{hr} \\
\text { Uncoated } \\
\text { concrete } \\
\text { wall: } 10.43 \\
\mathrm{ft}^{2} / \mathrm{hr} \\
\text { Coated } \\
\text { concrete } \\
\text { ceiling: } \\
25.19 \mathrm{ft} / \mathrm{hr} \\
\text { Note: the } \\
\text { production } \\
\text { rates were } \\
\text { based on } \\
\text { one } \\
\text { operator. }\end{array}$ & $\begin{array}{l}\text { Equipment } \\
\text { operators: } 2 \\
\text { Tender : } 1\end{array}$ & $\begin{array}{l}\text { Average } \\
\text { exposure } \\
\text { Dust level: } \\
\text { Negligible } \\
\\
\text { Noise level: } \\
104.1 \mathrm{dBA}\end{array}$ & $\begin{array}{l}\text { Rough, } \\
\text { bare, and } \\
\text { uneven } \\
\text { surface } \\
\text { Removal } \\
\text { depth } \\
\text { Coated } \\
\text { brick wall: } \\
0.039 \text { in. } \pm \\
0.065 \text { in. } \\
\text { Uncoated } \\
\text { concrete } \\
\text { wall: } 0.190 \\
\text { in. } \pm 0.122 \\
\text { in. } \\
\text { Coated } \\
\text { concrete } \\
\text { ceiling: } \\
\text { coating } \\
\text { removal } \\
\text { only }\end{array}$ & $\begin{array}{l}\text { Fine brick or } \\
\text { concrete powder }\end{array}$ & $\begin{array}{l}\text { Cooler } \\
\text { dryer CD- } \\
1300 \\
\$ 14,116 \\
\text { HEPA } \\
\text { filter and } \\
\text { kit } \\
\$ 2,273.00 \\
\text { Total: } \\
\$ 16,389\end{array}$ \\
\hline
\end{tabular}


Technology Class: Milling/Shaving

Name: Marcrist DTF25 Floor Shaver

Technology Description: The Marcrist DTF25 Floor Shaver is a self-propelled unit, which is capable of shaving a pre-determined amount of concrete from structures by using diamond blades. The shaving diamond blades are mounted on specially designed drum which rotates during operation. The waste material is collected via a dust shroud connected to vacuum extraction system. The DTF 25 is capable of shaving a $250 \mathrm{~mm}(9.8 \mathrm{in}$.) width and up to $15 \mathrm{~mm}$ ( 0.59 in.) depth with each pass. The system produces smooth finished surfaces, while no damage is conveyed to the surrounding material.

\begin{tabular}{|c|c|c|c|c|c|c|c|c|c|}
\hline $\begin{array}{c}\text { Equipment } \\
\text { Dimension/ } \\
\text { Weight }\end{array}$ & $\begin{array}{c}\text { Estimated } \\
\text { Capital } \\
\text { Cost }\end{array}$ & Benefits & Limitations & $\begin{array}{c}\text { Production } \\
\text { Rate }\end{array}$ & $\begin{array}{c}\text { Labor } \\
\text { Classification }\end{array}$ & $\begin{array}{c}\text { Environmental } \\
\text { Conditions }\end{array}$ & $\begin{array}{c}\text { End } \\
\text { Point } \\
\text { Achieved } \\
\end{array}$ & $\begin{array}{c}\text { Characteristics } \\
\text { of Waste }\end{array}$ & $\begin{array}{c}\text { Support } \\
\text { Equipment }\end{array}$ \\
\hline $\begin{array}{l}\text { 45.3" L X } \\
18.7 " \mathrm{~W} \times \\
39.4 " \mathrm{H} \\
\text { Weight } \\
\text { Machine and } \\
\text { Motor: } \\
253.5 \mathrm{LB} \\
\text { Advanced } \\
\text { Drive } \\
\text { system: } 44.1 \\
\text { lb. } \\
\text { Diamond } \\
\text { Drum: } 33.1 \\
\text { lb. } \\
\text { Total } \\
\text { Weight: } \\
\text { 330.7 lb. }\end{array}$ & $\$ 32,525.00$ & $\begin{array}{l}\text { Self propelled } \\
\text { reducing operator } \\
\text { fatigue. } \\
\text { Uses few controls } \\
\text { thus making it easy } \\
\text { to operate and learn. } \\
\text { Generates no } \\
\text { secondary waste. } \\
\text { Leaves surface } \\
\text { smooth and even for } \\
\text { repainting or reuse. } \\
\text { Depth of removal } \\
\text { can be set using a } \\
\text { gauge on the unit, } \\
\text { thus reducing } \\
\text { variability due to } \\
\text { the operator. } \\
\text { Relieves operator of } \\
\text { strong vibration. }\end{array}$ & $\begin{array}{l}\text { Production } \\
\text { rate } \\
\text { decreases as } \\
\text { the blades } \\
\text { wear out and } \\
\text { become less } \\
\text { sharp. } \\
\text { Requires a } \\
\text { strong } \\
\text { vacuum } \\
\text { system to } \\
\text { remove all } \\
\text { of the dust. }\end{array}$ & $\begin{array}{l}\text { Coated } \\
\text { concrete } \\
\text { floor: } 44.53 \\
\mathrm{ft}^{2} / \mathrm{hr} \\
\\
\text { Uncoated } \\
\text { concrete } \\
\text { floor: } 41.06 \\
\mathrm{ft}^{2} / \mathrm{hr}\end{array}$ & $\begin{array}{l}\text { Equipment } \\
\text { operators: } 1\end{array}$ & $\begin{array}{l}\text { Average } \\
\text { exposure } \\
\text { Dust level: } \\
\text { Negligible } \\
\\
\text { Noise level: } \\
94 \mathrm{dBA}\end{array}$ & $\begin{array}{l}\text { Smooth, } \\
\text { bare, even } \\
\text { surface } \\
\text { Removal } \\
\text { depth } \\
\text { Coated } \\
\text { concrete } \\
\text { floor: } \\
0.324 \text { in. } \\
\pm 0.0340 \\
\text { in. } \\
\text { Uncoated } \\
\text { concrete } \\
\text { floor: } \\
0.228 \pm \\
0.0198 \text { in. }\end{array}$ & $\begin{array}{l}\text { Gray concrete } \\
\text { powder }\end{array}$ & $\begin{array}{l}\text { Dust } \\
\text { Collector: } \\
\$ 10,000.00\end{array}$ \\
\hline
\end{tabular}


Technology Class: $\mathrm{CO}_{2}$ Blasting

\section{Name: $\mathrm{ROVCO}_{2}$}

Technology Description: $\mathrm{ROVCO}_{2}$ is a remotely operated $\mathrm{CO}_{2}$ blasting system. The system shoots pellets of dry ice propelled by high pressure air at the surface being cleaned. At the moment of impact, the dry ice pellets fracture and remove a layer of the contaminated surface. The pellets then turn to a gaseous state, which is vacuumed away by a built-in vacuum system with the debris of removed surface. The system is equipped with a front and a rear camera, and is connected by a tether to the control station where operators can adjust the operation of the blast nozzle and the movement of the vehicle.

\begin{tabular}{|c|c|c|c|c|c|c|c|c|c|}
\hline $\begin{array}{l}\text { Equipment } \\
\text { Dimension/ } \\
\text { Weight }\end{array}$ & $\begin{array}{c}\text { Estimated } \\
\text { Capital } \\
\text { Cost }\end{array}$ & Benefits & Limitations & $\begin{array}{c}\text { Production } \\
\text { Rate }\end{array}$ & $\begin{array}{c}\text { Labor } \\
\text { Classification }\end{array}$ & $\begin{array}{c}\text { Environmental } \\
\text { Conditions }\end{array}$ & $\begin{array}{l}\text { End Point } \\
\text { Achieved }\end{array}$ & $\begin{array}{c}\text { Characteristics } \\
\text { of Waste }\end{array}$ & $\begin{array}{c}\text { Support } \\
\text { Equipment }\end{array}$ \\
\hline Not available & $\$ 304,000$ & $\begin{array}{l}\text { Remote } \\
\text { operation } \\
\text { reduces risk } \\
\text { to working } \\
\text { personnel. } \\
\text { Use of } \mathrm{CO}_{2} \text { to } \\
\text { remove } \\
\text { contaminants } \\
\text { does not } \\
\text { generate } \\
\text { secondary } \\
\text { waste, thus } \\
\text { minimizing } \\
\text { waste } \\
\text { generation. }\end{array}$ & 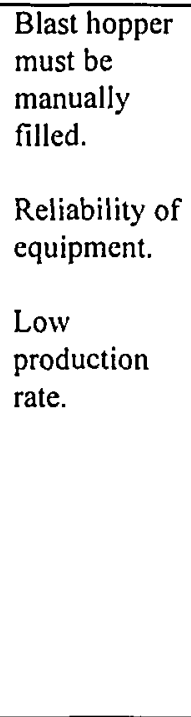 & $\begin{array}{l}\text { Coated steel } \\
\text { plates: } 4.22 \\
\mathrm{ft}^{2} / \mathrm{hr} \\
\text { Coated } \\
\text { concrete } \\
\text { floor: } 1.10 \\
\mathrm{ft}^{2} / \mathrm{hr}\end{array}$ & $\begin{array}{l}\text { Equipment } \\
\text { operators: } 2\end{array}$ & $\begin{array}{l}\text { Average exposure } \\
\text { Dust level: } \\
<17.4 \mathrm{mg} / \mathrm{m}^{3} \\
\\
\text { Noise level: } \\
117.3 \mathrm{dBA}\end{array}$ & $\begin{array}{l}\text { Coated } \\
\text { steel plates: } \\
\text { brush-off } \\
\text { finish } \\
\text { Coated } \\
\text { concrete } \\
\text { floor: } \\
\text { coating } \\
\text { not fully } \\
\text { removed }\end{array}$ & $\begin{array}{l}\text { Fine particles } \\
\text { and powder }\end{array}$ & $\begin{array}{l}\text { Air } \\
\text { Compressor: } \\
\$ 75,700 \\
\text { Air Cooler: } \\
\$ 9,700 \\
\text { Desiccant } \\
\text { Air Dryer: } \\
\$ 27,700 \\
\text { Carbon } \\
\text { Dioxide } \\
\text { Pelletizer: } \\
\$ 39,500 \\
\text { (optional) } \\
\text { Total: } \\
\$ 152,600\end{array}$ \\
\hline
\end{tabular}


Technology Class: Mechanical Scabbling

Name: Squirrel ${ }^{\circledR}$ - III Floor Scabbler Pentek Part No. Z- 003.

Technology Description: The Squirre ${ }^{\otimes}$ III is a pneumatic operated scabbler that operates in conjunction with an ultra-high performance HEPA-filtered vacuum system. Each Squirrel ${ }^{\oplus}$ III contains three 9-tooth Tungsten Carbide-Tipped Bits. The Squirrel ${ }^{\circledR}$ III incorporates unique vacuum flow designs, which provide high efficiency performance in contaminated or clean-room environments which require stringent control of dust, debris, and airborne contamination. The Squirrel ${ }^{\otimes}$ III is designed to tackle small jobs and to get into tight places near corners, wall/floor joints, floor penetrations, steps and under protruding equipment. The Squirre $\mathrm{l}^{\oplus}$ III is equipped with carrier wheels and a handle for easy transport around the job site. It is also designed to remove protective coatings, laitance, and concrete substrate in a single step-process. Surfaces are left clean with a uniform texture, and ready to receive new coatings.

\begin{tabular}{|c|c|c|c|c|c|c|c|c|c|}
\hline $\begin{array}{c}\text { Equipment } \\
\text { Dimension/ } \\
\text { Weight }\end{array}$ & $\begin{array}{c}\text { Estimated } \\
\text { Capital } \\
\text { Cost } \\
\end{array}$ & Benefits & Limitations & $\begin{array}{l}\text { Production } \\
\text { Rate }\end{array}$ & $\begin{array}{c}\text { Labor } \\
\text { Classification }\end{array}$ & $\begin{array}{c}\text { Environmental } \\
\text { Conditions }\end{array}$ & $\begin{array}{c}\text { End } \\
\text { Point } \\
\text { Achieved }\end{array}$ & $\begin{array}{c}\text { Characteristics } \\
\text { of Waste }\end{array}$ & $\begin{array}{c}\text { Support } \\
\text { Equipment }\end{array}$ \\
\hline $\begin{array}{l}12 " \mathrm{~L} \times 6 " \\
\mathrm{~W} \times 12 " \mathrm{H} \\
50 \mathrm{lb}\end{array}$ & $\$ 9,975.00$ & $\begin{array}{l}\text { Easy to operate, } \\
\text { requires little } \\
\text { training. } \\
\text { Leaves surface } \\
\text { smooth and even, } \\
\text { ready for repainting } \\
\text { or reuse. } \\
\text { Vacuum unit } \\
\text { minimizes need for } \\
\text { respiratory protection } \\
\text { for operating } \\
\text { personnel. } \\
\text { Unit is very } \\
\text { maneuverable and } \\
\text { reaches tight spots. } \\
\text { Equipment } \\
\text { incorporates } \\
\text { scabbling head } \\
\text { vibration isolation } \\
\text { technology, which } \\
\text { drastically reduces } \\
\text { operator fatigue. }\end{array}$ & $\begin{array}{l}\text { Equipment is } \\
\text { designed to be } \\
\text { used on small } \\
\text { or confined } \\
\text { areas instead of } \\
\text { large floor } \\
\text { surfaces. } \\
\text { The operator's } \\
\text { hand that } \\
\text { depresses the } \\
\text { trigger is } \\
\text { subjected to } \\
\text { some fatigue. } \\
\text { At the } \\
\text { demonstration, } \\
\text { one operator } \\
\text { taped the } \\
\text { trigger down } \\
\text { for continual } \\
\text { operation. }\end{array}$ & $\begin{array}{l}\text { Coated } \\
\text { concrete } \\
\text { floor: } \\
19.08 \mathrm{ft}^{2} / \mathrm{hr} \\
\text { Uncoated } \\
\text { concrete } \\
\text { floor: } \\
13.72 \mathrm{ft}^{2} / \mathrm{hr}\end{array}$ & $\begin{array}{l}\text { Equipment } \\
\text { operators: } 1\end{array}$ & $\begin{array}{l}\text { Average } \\
\text { exposure } \\
\text { Dust level: } \\
\text { Negligible } \\
\\
\text { Noise level: } \\
103.6 \mathrm{dBA}\end{array}$ & $\begin{array}{l}\text { Smooth, } \\
\text { bare, and } \\
\text { even } \\
\text { surface } \\
\text { Removal } \\
\text { depth } \\
\text { Coated } \\
\text { concrete } \\
\text { floor: } \\
0.144 \pm \\
0.06 \text { in. } \\
\text { Uncoated } \\
\text { concrete } \\
\text { floor: } \\
0.192 \text { in } \pm \\
0.072\end{array}$ & $\begin{array}{l}\text { Concrete } \\
\text { powder }\end{array}$ & $\begin{array}{l}75-90 \mathrm{cfm} \\
\text { of vacuum } \\
\text { system } \\
\text { with a } \\
\text { standard } \\
11 / 2 \text { in. } \\
\text { diameter } \\
\text { vacuum } \\
\text { hose. } \\
\text { Estimated } \\
\text { cost range } \\
\$ 2,000 \\
\text { to } \$ 20,000 \\
\text { depending } \\
\text { on features. }\end{array}$ \\
\hline
\end{tabular}


Technology Class: Scabbling, mechanical

Name: WallWalker ${ }^{\text {m }}$

Technology Description: The WallWalker ${ }^{\mathrm{TM}}$ system consists of four major subsystems: a motion control subsystem, a heavy-duty scabbler work head, an ultra-high performance vacuum system and a monorail mounting system.

The heart of the motion control subsystem is the system controller and operating software. The WallWalker ${ }^{\mathrm{TM}}$ system can be configured with a variety of controllers. The current system utilizes an IBM ThinkPad laptop computer and a Windows 95 based program.

The operating software allows the user to control the work head's position and define it's path of movement. The scabbler head can be "steered" using a manual up-downleft-right movement or can be moved along a predefined path (e.g. straight line, horizontal raster pattern, circle).

The scabbler head contains three single-piston scabblers mounted on an independent suspension. To provide an even surface profile, the three scabblers can be rotated.

Pentek's VAC-PAC was used as a vacuum system. The VAC-PAC contains pre-filters and a HEPA filter. The VAC-PAC features automatic self cleaning of the pre-filters using reverse-flow pulses of high pressure air, a feature that eliminates filter clogging, and allows for continuous vacuuming without interruptions or operator exposure due to filter replacement. The monorail mounting subsystem is designed for quick repositioning of the WallWalker ${ }^{\text {rM }}$ 's motors along the wall.

Two important safety features have been incorporated in the positioning trolleys. First, there is a solenoid-controlled brake pin on each trolley to ensure that it remains fixed in position during operations. The trolleys also incorporate proximity switches to ensure that the brake pin is fully engaged.

\begin{tabular}{|c|c|c|c|c|c|c|c|c|c|}
\hline $\begin{array}{c}\text { Equipment } \\
\text { Dimension/ } \\
\text { Weight }\end{array}$ & $\begin{array}{c}\text { Estimated } \\
\text { Capital } \\
\text { Cost }\end{array}$ & Benefits & Limitations & $\begin{array}{l}\text { Production } \\
\text { Rate }\end{array}$ & $\begin{array}{c}\text { Labor } \\
\text { Classification }\end{array}$ & $\begin{array}{l}\text { Environmental } \\
\text { Conditions }\end{array}$ & $\begin{array}{c}\text { End } \\
\text { Point } \\
\text { Achieved }\end{array}$ & $\begin{array}{c}\text { Characteristics } \\
\text { of Waste }\end{array}$ & $\begin{array}{c}\text { Support } \\
\text { Equipment }\end{array}$ \\
\hline $\begin{array}{l}\text { Not } \\
\text { available }\end{array}$ & $\begin{array}{l}\text { Locomotion } \\
\text { subsystem: } \\
\$ 150,000.00 \\
\text { Vacuum } \\
\text { subsystem: } \\
\$ 40,000.00 \\
\text { Scabbler } \\
\text { subsystem: } \\
\$ 65,000.00 \\
\text { Monorail } \\
\text { subsystem: } \\
\$ 15,000.00 \\
\text { Total: } \\
\$ 270,000.00\end{array}$ & $\begin{array}{l}\text { Unit is remote } \\
\text { controlled and easy } \\
\text { to operate. Unit is not } \\
\text { labor intensive. } \\
\text { Vacuum unit } \\
\text { minimizes need for } \\
\text { respiratory protection } \\
\text { for operating } \\
\text { personnel. } \\
\text { Unit is very } \\
\text { maneuverable. } \\
\text { The design of the } \\
\text { monorail allows the } \\
\text { scabbling unit to } \\
\text { move quickly from } \\
\text { one section to } \\
\text { another section, thus } \\
\text { benefiting } \\
\text { decontamination on } \\
\text { large areas. }\end{array}$ & $\begin{array}{l}\text { When used in } \\
\text { small areas the } \\
\text { removal gaps } \\
\text { are considerably } \\
\text { large. } \\
\text { Walls have to be } \\
\text { drilled all the } \\
\text { way through the } \\
\text { other side in } \\
\text { order to set up } \\
\text { the monorail } \\
\text { system. } \\
\text { Mobilization } \\
\text { procedure is } \\
\text { lengthy. } \\
\text { Not very } \\
\text { effective for } \\
\text { aggressive } \\
\text { removal of brick } \\
\text { walls. }\end{array}$ & $\begin{array}{l}\text { Coated } \\
\text { concrete } \\
\text { wall } \\
\text { (aggressive } \\
\text { removal): } \\
19.74 \mathrm{ft}^{2} / \mathrm{hr} \\
\\
\text { Coated } \\
\text { brick wall } \\
\text { (coating } \\
\text { removal): } \\
31.58 \mathrm{ft}^{2} / \mathrm{hr}\end{array}$ & $\begin{array}{l}\text { Equipment } \\
\text { operators: } 1\end{array}$ & $\begin{array}{l}\text { Average } \\
\text { exposure } \\
\text { Dust level: } \\
\text { Negligible } \\
\\
\text { Noise level: } \\
90.1 \text { dBA }\end{array}$ & 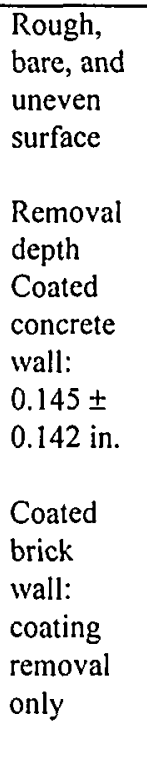 & $\begin{array}{l}\text { Brick or } \\
\text { concrete powder }\end{array}$ & $\begin{array}{l}\text { Vacuum } \\
\text { subsystem: } \\
\$ 40,000\end{array}$ \\
\hline
\end{tabular}




\section{B.2 UTILITY/MEDIA REQUIREMENT}

\begin{tabular}{|c|c|c|c|c|c|c|}
\hline $\begin{array}{c}\text { Technology } \\
\text { name }\end{array}$ & $\begin{array}{c}\text { Media type } \\
\text { and cost }\end{array}$ & $\begin{array}{c}\text { Media } \\
\text { usage rate }\end{array}$ & $\begin{array}{c}\text { Utility } \\
\text { requirement }\end{array}$ & $\begin{array}{c}\text { Operation and } \\
\text { maintenance requirements }\end{array}$ & $\begin{array}{l}\text { Availability } \\
\text { of equipment }\end{array}$ & $\begin{array}{l}\text { Equipment } \\
\text { portability }\end{array}$ \\
\hline $\begin{array}{l}\text { Advanced } \\
\text { Recyclable } \\
\text { Media System } \\
\text { (ARMSTM) }\end{array}$ & $\begin{array}{l}\text { ARMS }^{T M} \text { Aluminum } \\
\text { Oxide Fiber: } \\
\$ 2.20 / \text { lb }\end{array}$ & $\begin{array}{l}\text { Coated brick } \\
\text { wall: } 1.7 \mathrm{lb} / \mathrm{ft}^{2} \\
\text { Coated concrete } \\
\text { floor: } 1.1 \mathrm{lb} / \mathrm{ft}^{2}\end{array}$ & $\begin{array}{l}\text { Threee }-110 \\
\text { volt, } 20 \text { amp } \\
\text { outlets } \\
\text { One }-220 \\
\text { volt, single } \\
\text { phase, } 30 \mathrm{amp} \\
\text { outlet } \\
250 \mathrm{cfm}, 90 \\
\text { psi air } \\
\text { compressor }\end{array}$ & $\begin{array}{l}\text { - Oil air motors every eight ( } 8 \text { ) hours of } \\
\text { operation. } \\
\text { Grease sifter every } 40 \text { hours of } \\
\text { operation. }\end{array}$ & $\begin{array}{l}\text { Available off } \\
\text { the shelf ( } 1- \\
5 \text { Units) }\end{array}$ & $\begin{array}{l}2 \text { people and a } \\
\text { forklift needed } \\
\text { to move from } \\
\text { truck }\end{array}$ \\
\hline EBE $250 \mathrm{VHC}$ & $\overline{\mathrm{NA}}$ & $\begin{array}{l}\text { Concrete wall: } \\
2.05 \mathrm{lb} / \mathrm{ft}^{2} \\
\text { Coated brick } \\
\text { wall: NA }\end{array}$ & $\begin{array}{l}480 \text { Volt, } 3 \\
\text { phase, at } 60 \\
\text { amps and } 60 \\
\text { Hz. }\end{array}$ & $\mathrm{NA}$ & $\mathrm{NA}$ & $\begin{array}{l}\text { Forklift needed } \\
\text { to remove from } \\
\text { truck }\end{array}$ \\
\hline EBE 350 & $\begin{array}{l}\text { G-460 Steel Shot in } \\
50-\text { lb bags. } \\
\$ 0.40 / \text { lb. }\end{array}$ & $0.2 \mathrm{lb} / \mathrm{ft}^{2}$ & $\begin{array}{l}\text { Electricity: } \\
480 \text { volts, } 45 \\
\text { Amps }\end{array}$ & $\begin{array}{l}\text { - } \text { Adjustment of shrouds. } \\
\text { - } \quad \text { Change wear plates. } \\
\text { - } \quad \text { Lubrication of bearings. } \\
\text { - } \quad \text { Check oil in Compressor every } 200 \mathrm{hrs} \text {. } \\
\text { - } \quad \text { Check seace filters in vacuum unit. } \\
\end{array}$ & $\begin{array}{l}2-3 \text { week } \\
\text { turnaround }\end{array}$ & $\begin{array}{l}\text { Forklift needed } \\
\text { to remove from } \\
\text { truck }\end{array}$ \\
\hline
\end{tabular}




\begin{tabular}{|c|c|c|c|c|c|c|}
\hline $\begin{array}{l}\text { Technology } \\
\text { name }\end{array}$ & $\begin{array}{l}\text { Media type } \\
\text { and cost }\end{array}$ & $\begin{array}{c}\text { Media } \\
\text { usage rate }\end{array}$ & $\begin{array}{c}\text { Utility } \\
\text { requirement }\end{array}$ & $\begin{array}{c}\text { Operation and } \\
\text { maintenance requirements }\end{array}$ & $\begin{array}{c}\text { Availability } \\
\text { of equipment }\end{array}$ & $\begin{array}{l}\text { Equipment } \\
\text { portability }\end{array}$ \\
\hline LTC $1072 \mathrm{Pn}$ & $\begin{array}{l}\text { Steel Grit HG-40 } \\
\$ 0.35 / 1 \mathrm{~b}\end{array}$ & $\begin{array}{l}\text { Brick wall and } \\
\text { uncoated } \\
\text { concrete wall: } \\
0.6 \mathrm{lb} / \mathrm{ft}^{2} \\
\text { Coated concrete } \\
\text { ceiling: } 1.01 \\
\mathrm{lb} / \mathrm{ft}^{2} \\
\text { Note: Rate was } \\
\text { based on one } \\
\text { blast nozzle. }\end{array}$ & $\begin{array}{l}\text { Air } \\
\text { consumption: } \\
1300 \mathrm{cfm} @ \\
150 \text { psig. }\end{array}$ & $\begin{array}{l}\text { Schedule maintenance; check the equipment } \\
\text { every } 300 \text { blast hours, as per LTC's standard } \\
\text { maintenance check list. }\end{array}$ & $\begin{array}{l}2-3 \text { week } \\
\text { turnaround }\end{array}$ & $\begin{array}{l}\text { Forklift needed } \\
\text { to remove from } \\
\text { truck }\end{array}$ \\
\hline $\begin{array}{l}\text { Marcrist } \\
\text { DTF25 Floor } \\
\text { Shaver }\end{array}$ & $\begin{array}{l}\text { Segment Blades } \\
\text { (Diamond Drum): } \\
\$ 10,000.00 \\
\text { Blade Spacers: } \\
\$ 1,000.00\end{array}$ & $\begin{array}{l}0.000067 \\
\text { drum } / \mathrm{ft}^{2}\end{array}$ & $\begin{array}{l}\text { Electricity: } \\
480 \mathrm{~V}, 3 \text { phase }\end{array}$ & $\begin{array}{l}\text { - Replace diamond blades as required } \\
\text { - Regular cleaning and light greasing of } \\
\text { all moving parts. } \\
\text { All bearings should be checked after } \\
\text { extended use. } \\
\text { - The wheels of the DTF-25 and the } \\
\text { friction drive wheel should be cleaned } \\
\text { regularly with a wire brush. }\end{array}$ & $\begin{array}{l}8-10 \text { week } \\
\text { turnaround }\end{array}$ & $\begin{array}{l}\text { Forklift needed } \\
\text { to remove from } \\
\text { truck }\end{array}$ \\
\hline $\mathrm{ROVCO}_{2}$ & $\begin{array}{l}\mathrm{CO}_{2} \text { pellets }(24 \mathrm{hr} \\
\text { and } 48 \mathrm{hr} \text { mix, } 1 / 4 " \\
\text { pellets }) \$ 0.35 / \mathrm{lb}\end{array}$ & $1.76 \mathrm{gal} . / \mathrm{ft}^{2}$ & $\begin{array}{l}\text { Air } \\
\text { consumption: } \\
900 \mathrm{cfm} @ \\
350 \text { psig }\end{array}$ & $\begin{array}{l}\text { The helical wire used for the X-direction } \\
\text { motion of the COYOTEE end effector } \\
\text { should be replaced every } 40 \text { to } 70 \text { hours of } \\
\text { operation. }\end{array}$ & $\begin{array}{l}>6 \text { month } \\
\text { turnaround }\end{array}$ & $\begin{array}{l}\text { Forklift needed } \\
\text { to remove from } \\
\text { truck }\end{array}$ \\
\hline $\begin{array}{l}\text { Squirrel }{ }^{\circledR} \text { III } \\
\text { Floor Scabbler }\end{array}$ & $\begin{array}{l}\text { 9-Tooth Tungsten } \\
\text { Carbide-Tipped Bits } \\
\$ 327.60 \text { each (three } \\
\text { required) }\end{array}$ & $\begin{array}{l}0.000482 \text { set } / \mathrm{ft}^{2} \\
\text { (One set } \\
\text { contains three } \\
\text { 9-Tooth } \\
\text { Tungsten } \\
\text { Carbide-Tipped } \\
\text { Bits) } \\
\end{array}$ & $\begin{array}{l}\text { Air } \\
\text { consumption: } \\
60 \text { scf@ } 80 \\
\text { psig }\end{array}$ & $\begin{array}{l}\text { Daily maintenance consists of routine checks } \\
\text { of tool condition and periodic lubrication. } \\
\text { Specific items to be checked include: loose } \\
\text { or missing fasteners and lock wire; damaged } \\
\text { or worn air supply tubing; worn scabbling } \\
\text { bits; and worn brushes and rubber skirting. }\end{array}$ & $\begin{array}{l}\text { Available off } \\
\text { the shelf }\end{array}$ & $\begin{array}{l}\text { I person needed } \\
\text { to move from } \\
\text { truck }\end{array}$ \\
\hline
\end{tabular}




\begin{tabular}{|c|c|c|c|c|c|c|}
\hline $\begin{array}{c}\text { Technology } \\
\text { name }\end{array}$ & $\begin{array}{l}\text { Media type } \\
\text { and cost }\end{array}$ & $\begin{array}{c}\text { Media usage } \\
\text { rate }\end{array}$ & $\begin{array}{c}\text { Utility } \\
\text { requirement }\end{array}$ & $\begin{array}{c}\text { Operation and } \\
\text { maintenance requirements }\end{array}$ & $\begin{array}{c}\text { Availability } \\
\text { of equipment }\end{array}$ & $\begin{array}{l}\text { Equipment } \\
\text { portability }\end{array}$ \\
\hline WallWalker ${ }^{T M}$ & $\begin{array}{l}\text { Tungsten Carbide- } \\
\text { Tipped Bits (Three } \\
\text { bits total for one } \\
\text { scabbler head): } \\
\text { \$335/each. }\end{array}$ & $0.000042 \mathrm{set} / \mathrm{ft}^{2}$ & $\begin{array}{l}\text { Electricity: } \\
110 \mathrm{~V}, 20 \mathrm{amp} \\
\text { Air } \\
\text { compressor: } \\
400 \mathrm{cfm} @ \\
100 \text { psig }\end{array}$ & $\begin{array}{l}\text { The scabbler foam seal and scabbler bits } \\
\text { should be changed after } 24,000 \mathrm{ft}^{2} \text { of } \\
\text { operation. } \\
\text { The HEPA and roughing filters in the } \\
\text { VAC-PAC should be changed annually. } \\
\text { The wire ropes of the locomotion } \\
\text { subsystem should be inspected prior to } \\
\text { each use to ensure there is no fraying. } \\
\text { The mounting brackets, trolleys, and the } \\
\text { monorail should be inspected prior to } \\
\text { each use for signs of wear (e.g., cracks). }\end{array}$ & $\begin{array}{l}8-10 \text { week } \\
\text { turnaround }\end{array}$ & $\begin{array}{l}\text { Forklift needed } \\
\text { to remove from } \\
\text { truck }\end{array}$ \\
\hline
\end{tabular}

NA: not available 


\section{APPENDIX C}

\section{TECHNOLOGY VENDOR INFORMATION}




\begin{tabular}{|c|c|c|c|c|c|}
\hline Technology name & Vendor name & Vendor address & Phone number & Fax number & Service available \\
\hline $\begin{array}{l}\text { Advanced Recyclable } \\
\text { Media System } \\
\left(\text { ARMS }^{T M}\right)\end{array}$ & $\begin{array}{l}\text { Surface } \\
\text { Technology } \\
\text { Systems, Inc. }\end{array}$ & $\begin{array}{l}7857 \text { Freedom } \\
\text { Avenue NW } \\
\text { North Canton, Oh } 44720 \\
\text { Attn: Steven Pocock }\end{array}$ & $\begin{array}{l}(330) 497-5905 \\
(330) 497-5903\end{array}$ & $(330) 497-2045$ & $\begin{array}{ll} & \text { Provides service } \\
\text { - } & \text { Rents technology model } \\
\text { - } & \text { Will train site users for } 12 \\
& \text { hours } \\
\end{array}$ \\
\hline EBE 250 VHC & $\begin{array}{l}\text { Pegasus } \\
\text { International Inc. }\end{array}$ & $\begin{array}{l}106 \text { Railroad Street } \\
\text { Schenley, PA } 15682 \\
\text { Attn: Tom Bodkin } \\
\end{array}$ & (724) $845-2838$ & $(724) 845-1794$ & Not available \\
\hline EBE 350 & $\begin{array}{l}\text { Pegasus } \\
\text { International Inc. }\end{array}$ & $\begin{array}{l}106 \text { Railroad Street } \\
\text { Schenley, PA } 15682 \\
\text { Attn: Tom Bodkin }\end{array}$ & (724) 845-2838 & $(724) 845-1794$ & Not available \\
\hline LTC $1072 P n$ & $\begin{array}{l}\text { LTC Americas } \\
\text { Inc. }\end{array}$ & $\begin{array}{l}22446 \text { Davis Drive, Suite } \\
142 \\
\text { Sterling, VA } 20164 \\
\text { Attn: Robert Miller }\end{array}$ & $\begin{array}{l}800-822-2332 \\
(703) 406-3005\end{array}$ & $(703) 406-4523$ & $\begin{array}{ll} & \text { Sells technology model } \\
- & \text { Rents technology model } \\
\text { - } & \text { Will train site users for } 16 \\
& \text { hours } \\
\end{array}$ \\
\hline $\begin{array}{l}\text { Marcrist DTF25 Floor } \\
\text { Shaver }\end{array}$ & $\begin{array}{l}\text { Pegasus } \\
\text { International Inc. }\end{array}$ & $\begin{array}{l}106 \text { Railroad Street } \\
\text { Schenley, PA } 15682 \\
\text { Attn: Tom Bodkin }\end{array}$ & (724) 845-2838 & $(724) 845-1794$ & $\begin{array}{ll} & \text { Provides service } \\
\text { - } & \text { Sells technology model } \\
\text { - } & \text { Rents technology model } \\
\text { - } & \text { Will train site users for } 10 \\
& \text { hours } \\
\end{array}$ \\
\hline $\mathrm{ROVCO}_{2}$ & $\begin{array}{l}\text { Oceaneering } \\
\text { International, } \\
\text { Inc. }\end{array}$ & $\begin{array}{l}660 \text { Swift Blvd., Suite D } \\
\text { Richland, WA } 99352 \\
\text { Attn: Victor Renard }\end{array}$ & (509) 946-5170 & (509) 946-5261 & $\begin{array}{ll}- & \text { Provides service } \\
- & \text { Sells technology model }\end{array}$ \\
\hline $\begin{array}{l}\text { Squirrel }{ }^{8} \text { - III Floor } \\
\text { Scabbler }\end{array}$ & Pentek, Inc. & $\begin{array}{l}\text { 1026 Fourth Avenue } \\
\text { Coraopolis, PA } 15108 \\
\text { Attn: Sheldon Lefkowitz }\end{array}$ & $(412) 262-0725$ & $(412) 262-0731$ & $\begin{array}{ll} & \text { Provides service } \\
\text { - } & \text { Sells technology model } \\
\text { - } & \text { Rents technology model } \\
\text { - Will train site users for } 1 \\
\text { hours } \\
\end{array}$ \\
\hline WallWalker ${ }^{\mathrm{TM}}$ & Pentek, Inc. & $\begin{array}{l}\text { 1026 Fourth Avenue } \\
\text { Coraopolis, PA } 15108 \\
\text { Attn: Sheldon Lefkowitz }\end{array}$ & $(412) 262-0725$ & (412) 262-0731 & $\begin{array}{ll} & \text { Provides service } \\
\text { - } & \text { Sells technology model } \\
\text { - } & \text { Rents technology model } \\
\text { - } & \text { Will train site users } 8 \text { hours } \\
\end{array}$ \\
\hline
\end{tabular}




\title{
APPENDIX D
}

\section{IUOE HUMAN FACTORS ASSESSMENT REPORT SUMMARY}

\author{
DUST AND NOISE DATA
}


DUST AND NOISE DATA ${ }^{a}$

\section{METAL SURFACE REMOVAL TECHNOLOGY}

\begin{tabular}{|c|c|c|c|c|c|c|}
\hline \multirow{3}{*}{$\begin{array}{c}\text { Technology } \\
\text { name }\end{array}$} & \multicolumn{2}{|c|}{ Dust level $\left(\mathrm{mg} / \mathrm{m}^{3}\right)$} & \multicolumn{4}{|c|}{ Noise level } \\
\hline & \multirow[b]{2}{*}{ Area } & \multirow[b]{2}{*}{ Personal } & \multicolumn{2}{|c|}{ Average exposure (dBA) } & \multicolumn{2}{|c|}{$\begin{array}{c}\text { 8-hr. Projected dose (\%) } \\
\text { /resultant TWA (dBA) }\end{array}$} \\
\hline & & & Area & Personal & Area & Personal \\
\hline $\mathrm{ROVCO}_{2}$ & $\begin{array}{l}\text { Blasting head: } \\
<17.4^{\mathrm{b}}\end{array}$ & $\begin{array}{l}\text { Operator control station: } \\
<26.8^{\mathrm{b}}\end{array}$ & 117.3 & 86.9 & $4443 / 106.7$ & $117.3 / 89.0$ \\
\hline
\end{tabular}

\section{FLOOR SURFACE REMOVAL TECHNOLOGY}

\begin{tabular}{|c|c|c|c|c|c|c|}
\hline \multirow{3}{*}{$\begin{array}{l}\text { Technology } \\
\text { name }\end{array}$} & \multicolumn{2}{|c|}{ Dust level $\left(\mathrm{mg} / \mathrm{m}^{3}\right)$} & \multicolumn{4}{|c|}{ Noise level } \\
\hline & \multirow{2}{*}{ Area } & \multirow{2}{*}{ Personal } & \multicolumn{2}{|c|}{ Average exposure (dBA) } & \multicolumn{2}{|c|}{$\begin{array}{l}\text { 8-hr. Projected dose (\%) } \\
\text { /resultant TWA (dBA) }\end{array}$} \\
\hline & & & Area & Personal & Area & Personal \\
\hline $\begin{array}{l}\text { Marcrist } \\
\text { DTF25 Floor } \\
\text { Shaver }\end{array}$ & Negligible $^{c}$ & Negligible $^{d}$ & 94 & 85.3 & Not available & $\begin{array}{l}175^{c} / \text { Not } \\
\text { available }\end{array}$ \\
\hline $\mathrm{ROVCO}_{2}$ & Blasting head: $<17.4^{b}$ & $\begin{array}{l}\text { Operator control station: } \\
<26.8^{\mathrm{b}}\end{array}$ & 113.8 & 115.8 & $\begin{array}{l}10^{\prime} \text { from } \\
\text { blasting: } \\
2728 / 112.9\end{array}$ & $\begin{array}{l}\text { Operator } \\
\text { control station: } \\
3581 / 112.1\end{array}$ \\
\hline
\end{tabular}

a Data were provided by the Operating Engineers National Hazard Program.

b No mass difference was measured on the sample filter before and after sample collection, but the detection limit was not low enough to indicate that the samples were below the OSHA permissible exposure limit of $15 \mathrm{mg} / \mathrm{m}^{3}$ for total dust and the ACGIH threshold of $10 \mathrm{mg} / \mathrm{m}^{3}$.

c Sampling period was $25 \mathrm{~min}$. A much longer sampling period would be necessary to prove that the exposures were below the OSHA total dust standard.

d Sampling period was $20 \mathrm{~min}$. A much longer sampling period would be necessary to prove that the exposures were below the OSHA total dust standard.

e Data was projected based on a 30-minute sampling result. 
FLOOR SURFACE REMOVAL TECHNOLOGY (Continued)

\begin{tabular}{|c|c|c|c|c|c|c|}
\hline \multirow{3}{*}{$\begin{array}{l}\text { Technology } \\
\text { name }\end{array}$} & \multicolumn{2}{|c|}{ Dust level $\left(\mathrm{mg} / \mathrm{m}^{3}\right)$} & \multicolumn{4}{|c|}{ Noise level } \\
\hline & \multirow{2}{*}{ Area } & \multirow{2}{*}{ Personal } & \multicolumn{2}{|c|}{ Average exposure (dBA) } & \multicolumn{2}{|c|}{$\begin{array}{l}\text { 8-hr. Projected dose (\%) } \\
\text { /resultant TWA (dBA) }\end{array}$} \\
\hline & & & Area & Personal & Area & Personal \\
\hline $\begin{array}{l}\text { Squirrel }^{\otimes} \text { III } \\
\text { Floor Scabbler }\end{array}$ & Negligible & Negligible & 103.6 & 104 & $654.1 / 103.6$ & $699.7 / 104$ \\
\hline $\mathrm{ARMS}^{\mathrm{TM}}$ & $\begin{array}{l}\text { Inside blast chamber: } 459 \\
\text { Inside feed unit chamber: } \\
179\end{array}$ & 639 & $\begin{array}{l}\text { Outside } \\
\text { containment: } \\
108.1 \\
\text { Inside } \\
\text { containment: } \\
109.6\end{array}$ & $\begin{array}{l}\text { Average of feed } \\
\text { unit tender and } \\
\text { blast operator: } \\
108.8\end{array}$ & Not available & Not available \\
\hline EBE 350 & Not Available & & & & & \\
\hline
\end{tabular}

\section{WALL/CEILING SURFACE REMOVAL TECHNOLOGY}

\begin{tabular}{|c|c|c|c|c|c|c|}
\hline \multirow{3}{*}{$\begin{array}{l}\text { Technology } \\
\text { name }\end{array}$} & \multicolumn{2}{|c|}{ Dust Level $\left(\mathrm{mg} / \mathrm{m}^{3}\right)$} & \multicolumn{4}{|c|}{ Noise level } \\
\hline & \multirow{2}{*}{ Area } & \multirow{2}{*}{ Personal } & \multicolumn{2}{|c|}{ Average exposure (dBA) } & \multicolumn{2}{|c|}{$\begin{array}{c}\text { 8-hr. Projected dose (\%)/ } \\
\text { resultant TWA (dBA) }\end{array}$} \\
\hline & & & Area & Personal & Area & Personal \\
\hline$\overline{\text { LTC } 1072 \mathrm{Pn}}$ & Negligible & $\begin{array}{l}\text { Small blast head: } 139.664 \\
\text { Large blast head: } 34.965\end{array}$ & 104.1 & 116.9 & $761.6 / 104.1$ & $4173.8 / 116.9$ \\
\hline WallWalker $^{\mathrm{TM}}$ & Negligible & Negligible & 90.1 & Not available & $109.99 / 90.7$ & $\begin{array}{l}\text { Operator's } \\
\text { control station: } \\
91.2 / 89.3\end{array}$ \\
\hline
\end{tabular}


WALL/CEILING SURFACE REMOVAL TECHNOLOGY (Continued)

\begin{tabular}{|c|c|c|c|c|c|c|}
\hline \multirow{3}{*}{$\begin{array}{l}\text { Technology } \\
\text { name }\end{array}$} & \multicolumn{2}{|c|}{ Dust Level (mg/m $\left.{ }^{3}\right)$} & \multicolumn{4}{|c|}{ Noise level } \\
\hline & \multirow[b]{2}{*}{ Area } & \multirow[b]{2}{*}{ Personal } & \multicolumn{2}{|c|}{ Average exposure (dBA) } & \multicolumn{2}{|c|}{$\begin{array}{c}\text { 8-hr. Projected dose (\%)/ } \\
\text { resultant TWA (dBA) }\end{array}$} \\
\hline & & & Area & Personal & Area & Personal \\
\hline ARMS $^{\text {TM }}$ & $\begin{array}{l}\text { Inside blast chamber: } 459 \\
\text { Inside feed unit chamber: } \\
179\end{array}$ & 639 & $\begin{array}{l}\text { Outside } \\
\text { containment: } \\
108.1 \\
\text { Inside } \\
\text { containment: } \\
109.6\end{array}$ & $\begin{array}{l}\text { Average of feed } \\
\text { unit tender and } \\
\text { blast operator: } \\
108.8\end{array}$ & Not available & Not available \\
\hline EBE $250 \mathrm{VHC}$ & At blast head: 21.6 & Negligible & $\begin{array}{l}\text { Vacuum unit : } \\
84.75 \\
\text { General area: } \\
99.7\end{array}$ & $\begin{array}{l}\text { Forklift: } 83.8 \\
\text { Control panel: } \\
87.8\end{array}$ & $\begin{array}{l}\text { Vacuum unit: } \\
48.32 / 84.75 \\
\text { General area: } \\
387.16 / 99.76\end{array}$ & $\begin{array}{l}\text { Forklift: } 42.14 \\
/ 83.76\end{array}$ \\
\hline
\end{tabular}

